\title{
Optimizing the PBS1 Decoy System to Confer Resistance to Potyvirus Infection in Arabidopsis and Soybean
}

\author{
Sarah E. Pottinger, ${ }^{1}$ Aurelie Bak, ${ }^{2}$ Alexandra Margets, ${ }^{1}$ Matthew Helm, ${ }^{1,3}$ Lucas Tang, ${ }^{1}$ Clare Casteel, ${ }^{2}$ \\ and Roger W. Innes, ${ }^{1,+}$ \\ ${ }^{1}$ Indiana University, Department of Biology, Bloomington, IN 47405, U.S.A. \\ ${ }^{2}$ University of California, Department of Plant Pathology, Davis, CA 95616, U.S.A. \\ ${ }^{3}$ United States Department of Agriculture, Agricultural Research Service, Crop Production and Pest Control Research Unit, \\ West Lafayette, IN 47907, U.S.A.
}

Accepted 7 April 2020.

The Arabidopsis resistance protein RPS5 is activated by proteolytic cleavage of the protein kinase PBS1 by the Pseudomonas syringae effector protease AvrPphB. We have previously shown that replacing seven amino acids at the cleavage site of PBS1 with a motif cleaved by the NIa protease of turnip mosaic virus (TuMV) enables RPS5 activation upon TuMV infection. However, this engineered resistance conferred a trailing necrosis phenotype indicative of a cell-death response too slow to contain the virus. We theorized this could result from a positional mismatch within the cell between PBS1 ${ }^{\text {TuMV }}$, RPS5, and the NIa protease. To test this, we relocalized PBS1 ${ }^{\text {TuMv }}$ and RPS5 to cellular sites of NIa accumulation. These experiments revealed that relocation of RPS5 away from the plasma membrane compromised RPS5-dependent cell death in Nicotiana benthamiana, even though PBS1 was efficiently cleaved. As an alternative approach, we tested whether overexpression of plasma membrane-localized PBS1 ${ }^{\text {TuMV }}$ could enhance RPS5 activation by TuMV. Significantly, overexpressing the PBS1 ${ }^{\text {TuMV }}$ decoy protein conferred complete resistance to TuMV when delivered by either agrobacterium or by aphid transmission, showing that RPS5-mediated defense responses are effective against bacterial and viral pathogens. Lastly, we have now extended this PBS1 decoy approach to soybean by modifying a soybean PBS1 ortholog to be cleaved by the NIa protease of soybean mosaic virus (SMV). Transgenic overexpression of this soybean PBS1 decoy conferred immunity to

The authors have filed for and have been issued patents on the PBS1 decoy technology. Commercial development of this technology is currently being pursued with the support of a crop biotechnology company. Mention of trade names or commercial products in this publication is solely for the purpose of providing specific information and does not imply recommendation or endorsement by the United States Department of Agriculture. USDA is an equal opportunity provider and employer.

${ }^{\dagger}$ Corresponding author: R. W. Innes; E-mail: rinnes@indiana.edu

Funding: This research was funded by the United States National Science Foundation (Division of Integrative Organismal Systems award number IOS-1551452 to R. W. Innes). S. E. Pottinger was supported by a Carlos Miller fellowship from the Indiana University Foundation. M. Helm was supported by a predoctoral fellowship from the United States Department of Agriculture National Institute of Food and Agriculture (award number 2018-67011-28023).

*The $\boldsymbol{e}$-Xtra logo stands for "electronic extra" and indicates supplementary materials are published online.

(c) 2020 The American Phytopathological Society
SMV, demonstrating that we can use endogenous PBS1 proteins in crop plants to engineer economically relevant disease resistant traits.

Keywords: defense signaling pathways, disease resistance, PBS1, plant biotechnology, RPS5, resistance genes

The Arabidopsis disease resistance protein RESISTANCE TO PSEUDOMONAS SYRINGAE 5 (RPS5) confers resistance to Pseudomonas syringae through the detection of the effector protein AvrPphB (Simonich and Innes 1995). AvrPphB is a cysteine protease that targets serine-threonine kinases involved in pathogen-associated molecular pattern (PAMP)-triggered immunity (Shao et al. 2003; Zhang et al. 2010). One of these kinases, PBS1, forms a preactivation complex with RPS5 and triggers RPS5 activation upon AvrPphB-dependent cleavage (Ade et al. 2007). It is the resulting conformational change in PBS1 that activates RPS5 rather than PBS1 cleavage itself. This is shown by the observation that insertion of three alanine residues into the cleavage loop of PBS1 is sufficient to activate RPS5 in the absence of PBS1 cleavage (DeYoung et al. 2012). Therefore, RPS5 can theoretically confer resistance to any pathogen with an effector capable of causing the necessary conformational change in PBS1.

The work presented here follows on from a study, published by Kim et al. (2016), in which novel resistance to turnip mosaic virus (TuMV) was engineered by insertion of a cleavage motif for the NIa protease of TuMV into PBS1 (PBS1 ${ }^{\text {TuMV }}$ ). However, the engineered resistance was not complete, as transgenic PBS1 ${ }^{\text {TuMV }}$ Arabidopsis plants displayed a trailing necrosis phenotype when challenged with TuMV. This suggests the immune response produced by this engineered resistance was too slow to prevent the spread of viral infection (Kim et al. 2016). We theorized this could be due to a positional mismatch within the cell between the PBS1/RPS5 complex and the viral protease. Both PBS1 and RPS5 are tethered to the plasma membrane (PM), along with AvrPphB (Dowen et al. 2009; Qi et al. 2012). However, the TuMV NIa protease is primarily located at the endoplasmic reticulum (ER) and in the nucleus (Cotton et al. 2009; Restrepo et al. 1990), raising the possibility that PBS $1^{\text {TuMV }}$ is only cleaved late in the infection process, after high levels of viral proteins have accumulated and neighboring cells have already been infected. To test this hypothesis, we used genetic techniques to relocate the PBS $1^{\text {TuMV }} /$ RPS5 complex to regions of NIa accumulation and then assessed for improved activation of RPS5. We also tested 
whether overexpression of PM-localized PBS $1^{\text {TuMV }}$ could enhance resistance. These experiments revealed that, while the localization of PBS1 $1^{\text {TuMV }}$ does not affect its ability to be cleaved by NIa protease, RPS5 is unable to induce cell death unless it is located at the PM. However, overexpression of PMlocalized PBS1 $1^{\text {TuMV }}$ conferred complete resistance to TuMV systemic infection, eliminating the trailing necrosis phenotype. We also show that the PBS1 decoy system can be deployed in crop plants, as transgenic overexpression of a soybean PBS1 protein engineered to be cleavable by the NIa protease of soybean mosaic virus (SMV) conferred immunity to SMV in soybean. Because the PBS1 gene is highly conserved across angiosperms (Caldwell and Michelmore 2009), this last finding has broad implications for engineering novel disease resistance traits in crops.

\section{RESULTS}

PBS1 ${ }^{\text {TuMv }}$ and RPS5 can be relocated

to various subcellular compartments

by replacing their $\mathrm{N}$-terminal acylation motifs

with other subcellular targeting sequences.

To test whether the PBS1/RPS5 system remains functional when not at the PM, we modified acylation motifs present in the N-termini of PBS1 and RPS5, which anchor these proteins to the PM (Qi et al. 2014). Specifically, we generated dexamethasone-inducible constructs that targeted RPS5 and PBS1 to the nucleus, cytoplasm, and to ER-derived membrane complexes induced under TuMV infection (discussed below).
These constructs were then fused to a C-terminal super yellow fluorescent protein (sYFP) and were transiently expressed in Nicotiana benthamiana.

As shown in Figure 1, confocal microscopy analyses revealed that all relocalization constructs accumulated at subcellular sites other than the PM. Constructs containing an Nterminal nuclear localization signal (NLS) produced a strong accumulation in the nucleus $24 \mathrm{~h}$ after the induction of gene expression. However, RPS5 with a C-terminal NLS accumulated predominately in the cytoplasm. The cytoplasmic PBS $1^{\text {TuMV }}$-s YFP construct produced a strong cytoplasmic accumulation as well as accumulation in the nucleus, while cytoplasmic RPS5-sYFP accumulated to lower levels (Fig. 1). This latter observation is consistent with the reduced stability of a RPS5 ${ }^{\mathrm{G} 2 \mathrm{~A} / 3 \mathrm{~A}, \mathrm{C} 4 \mathrm{~A}}$-sYFP construct, which has been reported previously (Qi et al. 2012).

To more fully match the localization of the PBS1/RPS5 complex to sites of viral replication, the acylation sites of PBS $1^{\text {TuMV }}$ and RPS5 were replaced with the complete TuMV $6 \mathrm{~K} 2$ protein sequence. Under conditions of viral infection, the $6 \mathrm{~K} 2$ protein has been shown to manipulate host endomembranes into viral 'replication factories' (Cotton et al. 2009). We predicted that fusion of the $6 \mathrm{~K} 2$ protein to the N-termini of PBS $1^{\text {TuMV }}$ and RPS5 would localize them to these viral replication factories during infection and, possibly, to ER-derived structures in the absence of virus. The $6 \mathrm{~K} 2-\mathrm{PBS} 1^{\mathrm{TuMV}}$-sYFP accumulated on the surface of chloroplasts and caused chloroplasts to clump (Fig. 1; Supplementary Fig. S1), as has been previously shown for 6K2-YFP (Wei et al. 2010). 6K2-RPS5-sYFP
A
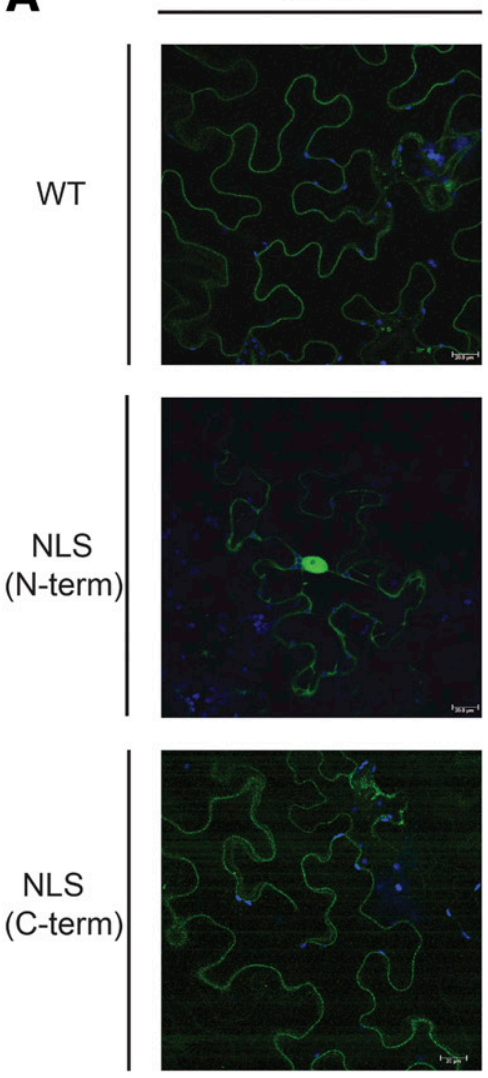
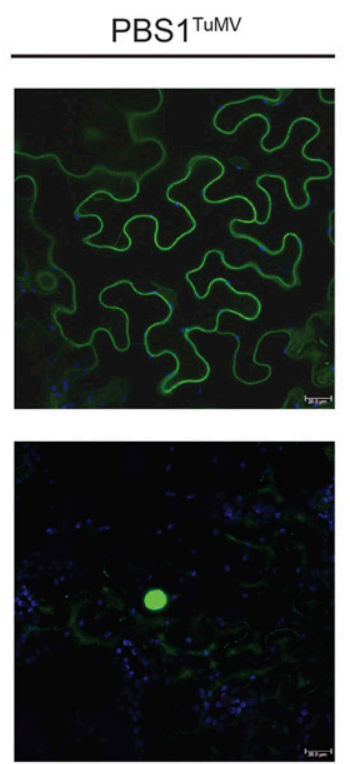

B

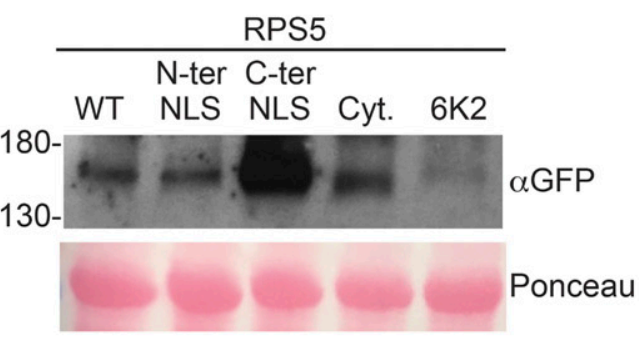

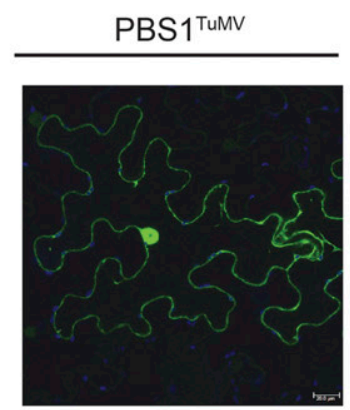

$6 \mathrm{~K} 2$
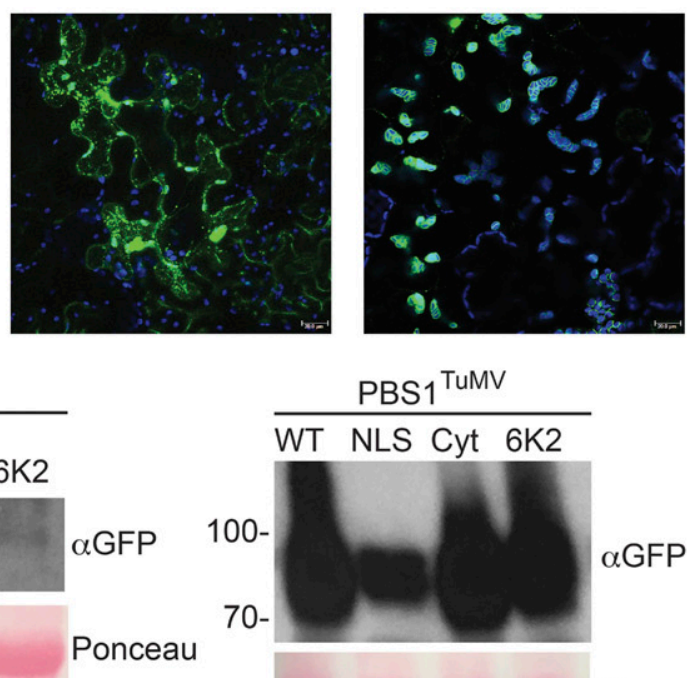

Ponceau

Fig. 1. Subcellular localization of the PBS1 $1^{\text {TuMV }}$ and RPS5 constructs. A, Fluorescence images showing the expression and localization of relocalized PBS1 $1^{\text {TuMV }}$-sYFP and RPS5-sYFP at $24 \mathrm{~h}$ after the induction of gene expression in Nicotiana benthamiana. Each image is a Z-stack comprised of five single sections. The scale bar represents $20 \mu \mathrm{m}$. Each construct was imaged independently three times. B, Immunoblots showing protein accumulation at $24 \mathrm{~h}$ postinduction of gene expression. 
accumulated in vesicle-like puncta within the cytoplasm (Fig. 1). Together, these data suggest that RPS5 and PBS1 ${ }^{\text {TuMV }}$ can be relocalized to other subcellular compartments.

\section{Relocalized PBS1 ${ }^{\text {TuMV }}$ is still cleaved by the TuMV NIa protease.}

We next tested whether relocalized PBS $1^{\text {TuMV }}$ is still capable of interacting with, and being cleaved by, the TuMV NIa protease. All relocalized PBS1 $1^{\text {TuMV }}$ constructs showed a robust expression at $6 \mathrm{~h}$ after dexamethasone induction (Fig. 2); however, the NLS-PBS $1^{\text {TuMV }}$ construct was expressed at a reduced level, consistent with that shown in Figure 1. We therefore assessed whether these PBS1 $1^{\text {TuMV }}$ derivatives could be efficiently cleaved by TuMV NIa protease in their new locations. As previously shown, wild-type (WT) PM-localized $\mathrm{PBS}^{\mathrm{TuMV}}$ was readily cleaved by the TuMV NIa protease at $6 \mathrm{~h}$ postinduction (Fig. 2) (Kim et al. 2016). NLS-PBS1 $1^{\text {TuMV }}$ was also cleaved, but its cleavage products accumulated to lower levels compared with those of PM-localized PBS1 ${ }^{\text {TuMV }}$ cleavage products, likely because the full-length protein also accumulated to lower levels. Both the 6K2- and cytoplasmiclocalized PBS1 $1^{\text {TuMV }}$-HA (hemagglutinin) cleavage products displayed accumulation similar to WT. The observation that PBS $1^{\text {TuMV }}$ could be cleaved regardless of subcellular location indicates that TuMV NIa is present in all these locations, at least when overexpressed in $N$. benthamiana.

\section{Relocalized RPS5/PBS1 ${ }^{\text {TuMv }}$ complexes are unable to activate programmed cell death.}

Having confirmed that relocalized $P B S 1^{\text {TuMV }}-\mathrm{HA}$ is efficiently cleaved by the TuMV NIa protease, we next tested whether colocalized PBS1 $1^{\text {TuMV }}$ and RPS5 could still activate programmed cell death when transiently coexpressed in $N$. benthamiana. The PM-localized WT RPS5/PBS1 $1^{\text {TuMV }}$ complex induced a robust cell death in $N$. benthamiana leaves when coexpressed with TuMV NIa protease (Fig. 3A). However, none of the relocalized RPS5/PBS $1^{\text {TuMV }}$ complexes were able to do so, suggesting that RPS5 may not function in these locations. The observation that RPS5 may need to reside at the PM to induce cell death led us to test whether relocalized $\mathrm{PBS}^{\text {TuMV }}$ can activate PM-localized RPS5, as this may still

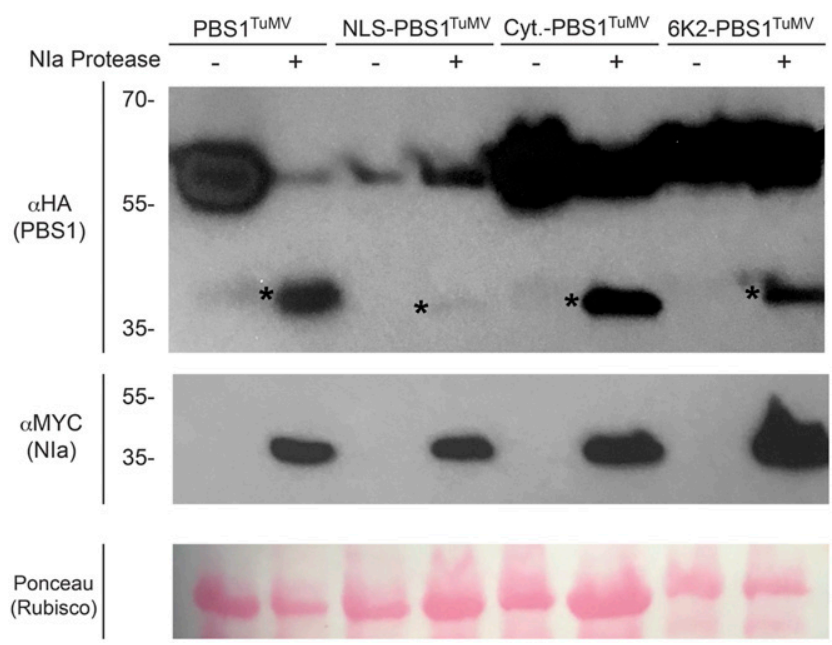

Fig. 2. Turnip mosaic virus (TuMV) NIa-mediated cleavage of the relocalized PBS1 $1^{\text {TuMV }}$ constructs in Nicotiana benthamiana. Immunoblot showing the expression of relocalized PBS $1^{\text {TuMV }}$-HA (hemagglutinin) constructs and their cleavage in the presence of MYC-tagged TuMV NIa Protease. At $6 \mathrm{~h}$ after the induction of gene expression, total protein was extracted and immunoblotted. Ponceau $\mathrm{S}$-stained blots are shown to assess variability in sample loading. enable a more rapid detection of TuMV NIa protease than previously seen in the PBS1 decoy system (Kim et al. 2016). We tested each modified PBS $1^{\text {TuMV }}$ construct for activation of WT RPS5. However, only the 6K2-PBS1 $1^{\text {TuMV }}$ construct showed a cell-death response (Fig. 3A). These results indicate that relocalization of PBS1 $1^{\text {TuMV }}$ away from the PM eliminates its ability to activate RPS5-dependent hypersensitive response (HR), except for the 6K2-PBS1 ${ }^{\text {TuMV }}$ construct. Notably, this is the construct that localized around the periphery of chloroplasts (Fig. 1; Supplementary Fig. S1) and, perhaps, reflects the close association of chloroplasts with the PM.

To test more directly whether RPS5 can activate cell death from locations other than the PM, we used an autoactive mutant of RPS5 containing a D266E substitution (RPS5 ${ }^{\mathrm{D} 266 \mathrm{E}}$ ), which constitutively activates cell death even in the absence of PBS1 (Ade et al. 2007). Significantly, relocalized RPS5 ${ }^{\text {D266E }}$ was unable to induce cell death when transiently expressed in $N$. benthamiana, while PM-localized RPS5 $5^{\mathrm{D} 266 \mathrm{E}}$ triggered a strong cell-death response (Fig. 3B). This suggests that the failure of the relocalized PBS1 ${ }^{\text {TuMV }} /$ RPS5 complex to induce cell death is likely a result of RPS5 requiring PM localization to activate cell death rather than an inability of cleaved PBS $1^{\text {TuMV }}$-HA to activate RPS5. To ensure that the lack of cell death was not due to the $\mathrm{N}$-terminal relocalization tags impairing the function of RPS5, a C-terminal NLS construct was tested (Fig. 3C). The RPS5-NLS construct also showed no cell death when expressed with NLS-PBS $1^{\text {TuMV }}$ and TuMV NIa or when autoactive.

Overall, these results suggest that relocalization of RPS5 impairs its ability to activate cell death, not through impairing its accumulation (Fig. 3D) but through disrupting an as-yetunknown signaling pathway.

\section{Expression of 6K2-PBS1 ${ }^{\text {TuMV }}$ in Arabidopsis does not complement a pbs 1 loss-of-function mutation.}

As 6K2-PBS1 ${ }^{\text {TuMV }}$ could induce cell death in N. benthamiana when coexpressed with WT RPS5 and TuMV NIa protease, we proceeded to assess whether this construct could confer resistance to TuMV infection in transgenic Arabidopsis plants. Transgenic lines expressing 6K2-PBS $1^{\text {TuMV }}$ under a $35 \mathrm{~S}$ promoter were generated in $p b s 1$ and rps 5 mutant backgrounds. The rps 5 background was used to assess whether any observed resistance was dependent on RPS5, while the pbs 1 line was used to eliminate competition with the WT PBS1 for RPS5 association. When these lines were infected with TuMV (6K2-GFP), systemic spread of TuMV was observed 3 weeks after inoculation (Fig. 4A). Systemic infection was verified by immunoblot analysis (Fig. 4B). This result, combined with the transient expression assays described above, indicate that relocalization of $P B S 1^{\text {TuMV }}$ to sites of viral replication does not enhance the efficacy of the RPS5-PBS1 decoy system.

\section{Overexpression of PBS1 ${ }^{\text {TuMV }}$ in Arabidopsis confers complete immunity to TuMV.}

As an alternative approach, we tested whether overexpressing PM-localized PBS1 $1^{\text {TuMV }}$ in Arabidopsis would enhance resistance and ameliorate the trailing necrosis phenotype, as a correlation was observed previously between TuMV resistance and the level of PBS $1^{\text {TuMV }}$ expression (Kim et al. 2016). Three independent homozygous lines expressing HAtagged $\mathrm{PBS} 1^{\text {TuMV }}$ under a $35 \mathrm{~S}$ promoter were generated in WT Col-0, pbs1, and rps5 backgrounds. As with the 6K2PBS1 $1^{\text {TuMV }}$ lines, the rps 5 background was used to confirm dependency on RPS5 and the $p b s 1$ line was used to ensure there would be no loss of signaling efficiency through competition with WT PBS1 protein for association with RPS5. The stable overexpression of PBS1 $1^{\mathrm{TuMV}}$ in these lines appeared to have no 
fitness consequences, as plants grew similarly to WT and, except for $p b s 1$ lines 1-5 and 2-1, produced an equivalent amount of seed (Supplementary Fig. S2).

Transgenic lines were inoculated with TuMV (6K2-GFP) using Agrobacterium-mediated delivery and were assessed for TuMV accumulation in the noninoculated, systemic leaves via ultraviolet light imaging at 3 weeks postinfection (Fig. 5A). Consistent with our hypothesis, WT Col-0 and pbsl genotypes overexpressing PBS1 $1^{\text {TuMV }}$ displayed complete resistance to TuMV. In contrast, the rps 5 lines overexpressing PBS $1^{\text {TuMV }}$ showed systemic green fluorescent protein (GFP) fluorescence derived from virally produced $6 \mathrm{~K} 2-\mathrm{GFP}$, indicative of successful TuMV infection (Fig. 5A). The lines expressing PBS $1^{\text {TuMV }}$ under a native promoter showed the trailing necrosis phenotype previously published (Kim et al. 2016). These data establish that TuMV resistance in the WT and pbs 1 transgenic lines is dependent on RPS5 expression and the expression level of PBS1 $1^{\mathrm{TuMV}}$. These results were verified using immunoblot analyses (Fig. 5B). We thus conclude that the trailing necrosis phenotype originally observed in the PBS1/RPS5 decoy system (Kim et al. 2016) can be overcome through overexpression of the decoy protein. Furthermore, expression of PBS $1^{\text {TuMV }}$ in a Col-0 background does not compromise the recognition of AvrPphB. As shown in Figure 6, both the $35 \mathrm{~S}$ and native

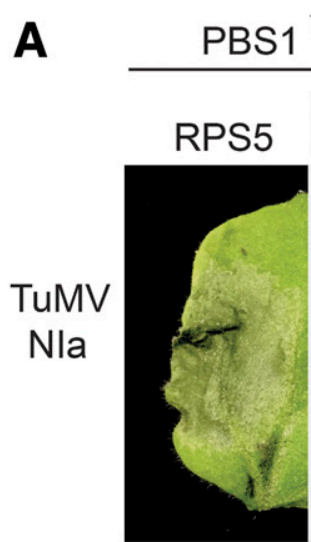

\section{TuMV}

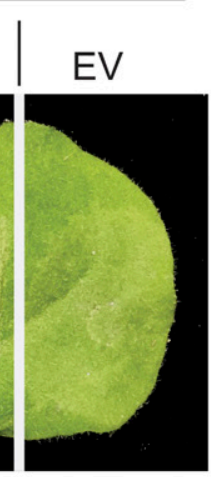

B

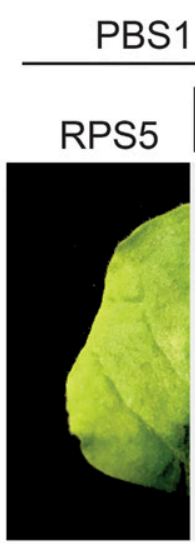

TuMV
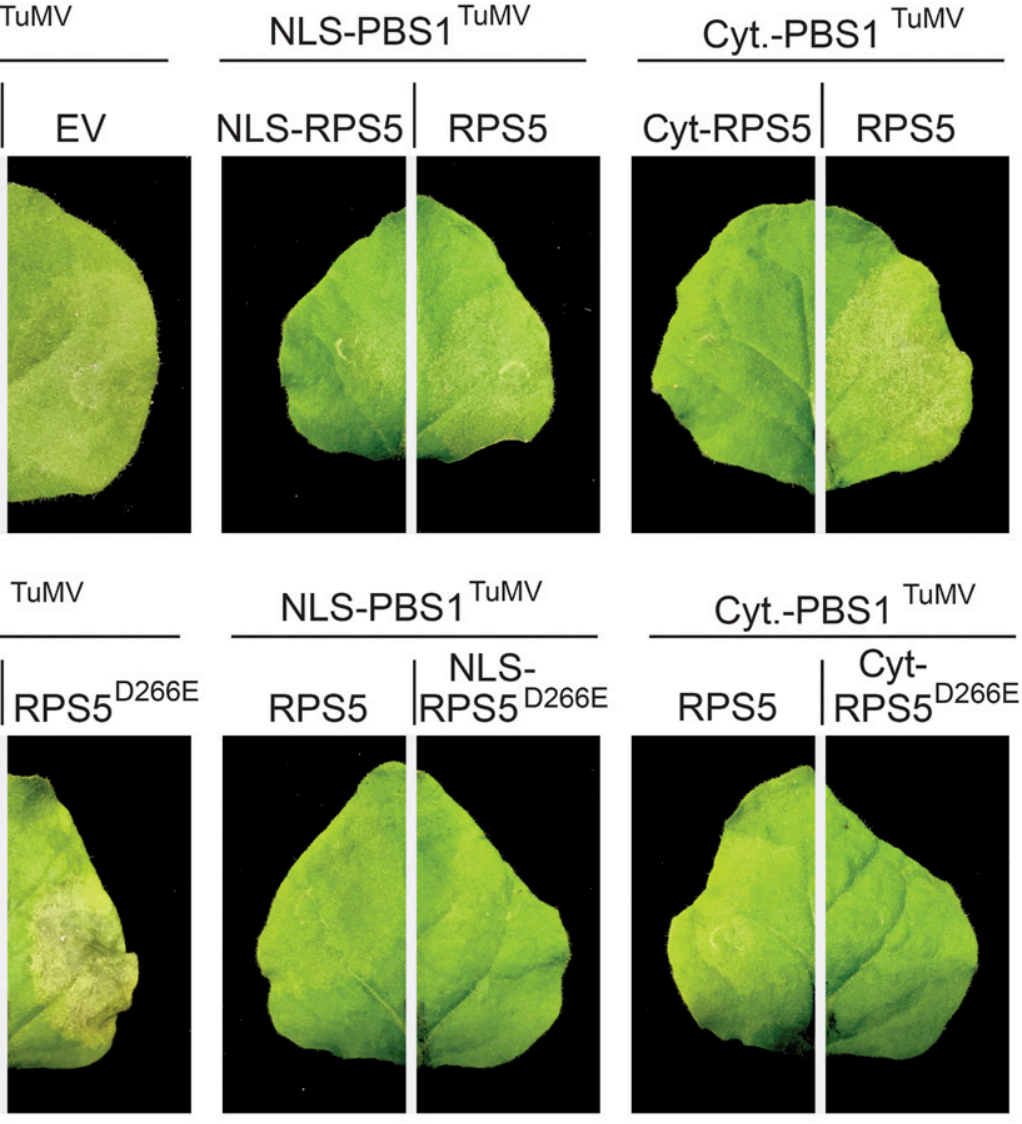

D
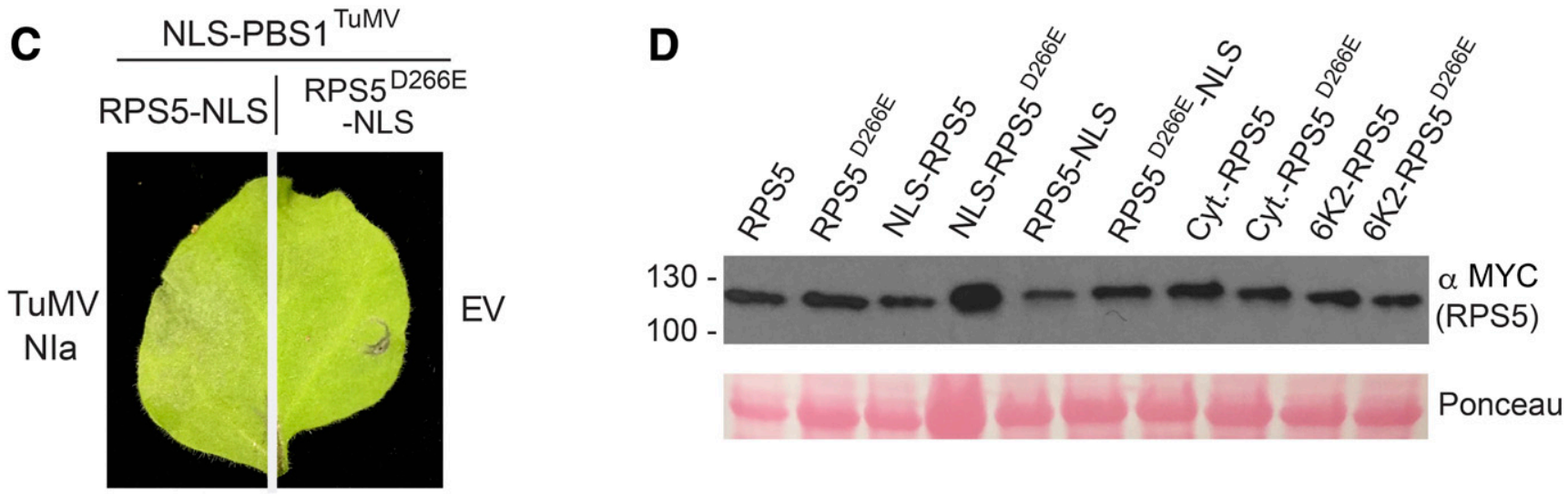

Fig. 3. Relocalized RPS5 is unable to signal for cell death. A, Photographs showing programmed cell death elicited by relocalized PBS1 ${ }^{\text {TuMV }}$-HA (hemagglutinin) and either plasma membrane (PM)-localized RPS5-MYC or relocalized RPS5-MYC constructs in response to turnip mosaic virus (TuMV) NIa protease. B, Cell-death responses elicited by wild-type (WT) and relocalized autoactive RPS5 (RPS5 ${ }^{\mathrm{D} 26 \mathrm{E}}$-MYC) when coexpressed with their corresponding PBS1 ${ }^{\text {TuMV }}$ construct. C, Cell-death responses elicited by RPS5-NLS-MYC when coexpressed with NLS-PBS1 ${ }^{\text {TuMV }}$-HA, and TuMV NIa and autoactive RPS5 $^{\text {D266E }}$-NLS-MYC. NLS = nuclear localization signal. Images in A, B, and C were taken at $24 \mathrm{~h}$ after the induction of gene expression in transiently transformed Nicotiana benthamiana leaves. Representative leaves are shown. D, Immunoblots showing the protein accumulation of WT and RPS5 ${ }^{\mathrm{D} 266 \mathrm{E}}$-MYC constructs at $6 \mathrm{~h}$ after the induction of gene expression. Samples were taken early to avoid tissue degradation during the cell-death response. 
promoter PBS $1^{\text {TuMV }}$ lines in a Col-0 background were capable of AvrPphB recognition, whereas the lines in the rps 5 background showed a response to AvrPphB comparable to that of the empty vector. Interestingly, one of the transgenic lines in the pbs 1 background showed HR levels in response to AvrPphB that were above background. This suggests that AvrPphB may still be able to cleave PBS $1^{\text {TuMV }}$ at a low level, although it is unclear why this was observed in just a single line, when all three lines displayed similar expression of PBS $1^{\text {TuMV }}$ (Fig. 5B).

To confirm that $35 \mathrm{~S}$-driven overexpression of PBS1 ${ }^{\text {TuMV }}$ confers resistance to TuMV, we also conducted infection assays using aphid transmission, which is the natural vector for TuMV infection (Shattuck 2010). Homozygous lines expressing 35S: PBS $1^{\text {TuMV }}$ were inoculated with aphids that had recently been

A

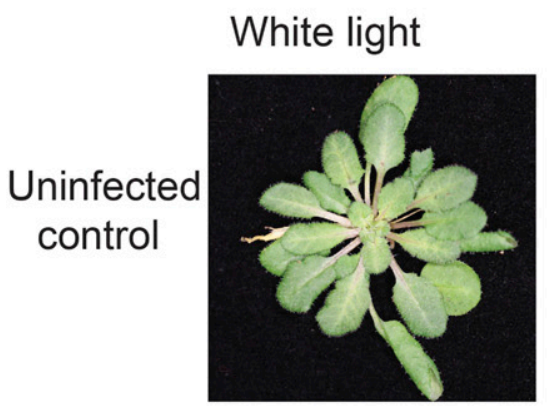

\section{UV light}
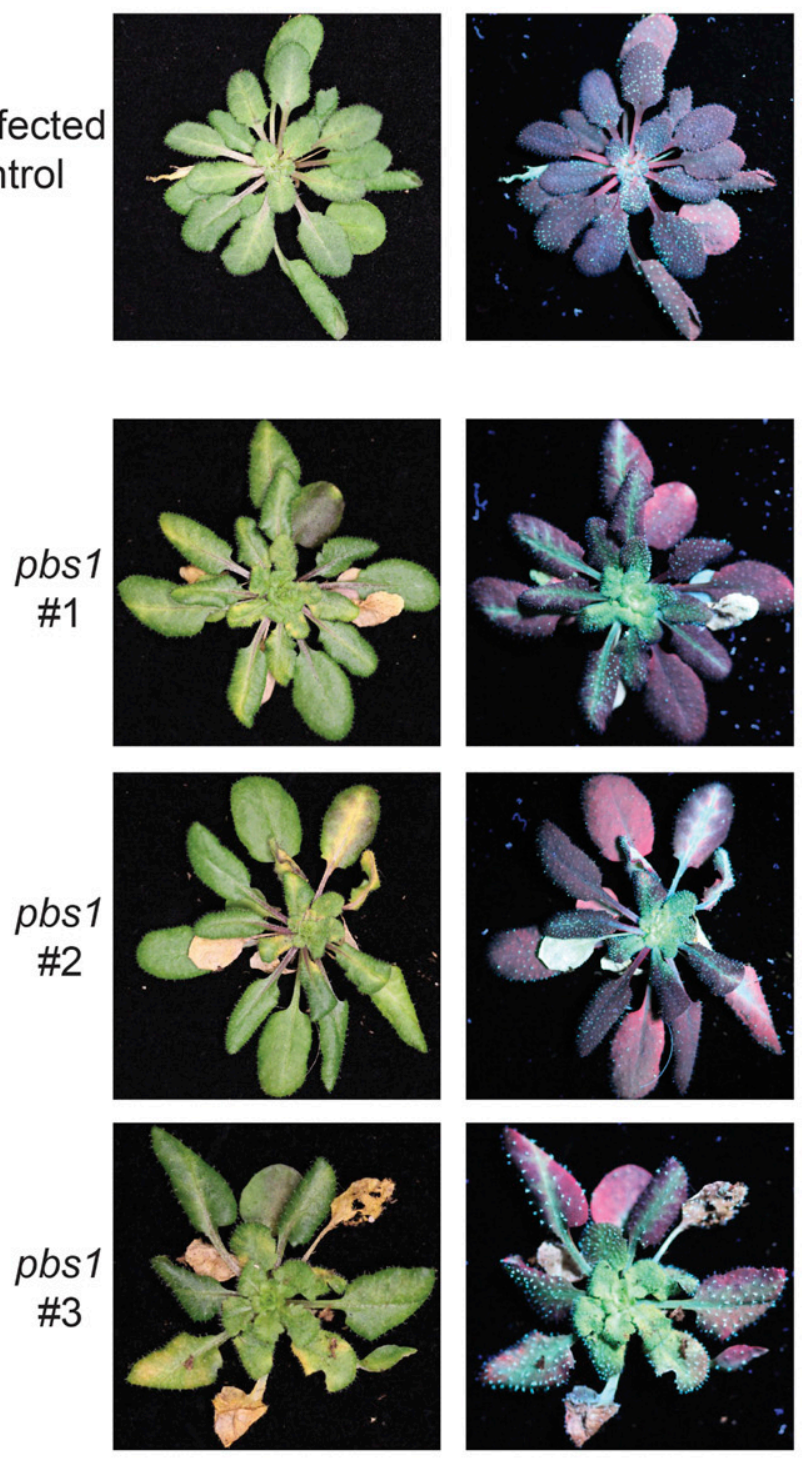

feeding on plants infected with TuMV (6K2:GFP) (Walsh and Jenner 2002). Significantly, the pbsl lines overexpressing PBS $1^{\text {TuMV }}$ displayed no observable viral symptoms 2 weeks postinfection (Fig. 7A). In the WT Col-0 background, viral symptoms were only observed in the final of three replicates, in two of the 10 plants tested. Results from the final replicate are shown in Figure 7. The rps5 lines, however, showed a strong GFP accumulation (Fig. 7A) caused by TuMV-produced 6K2GFP, as expected. These results were verified using immunoblot analysis (Fig. 7B). Here, PBS1 ${ }^{\text {TuMV }}$ expression levels are shown to be more variable, possibly due to increased protein turnover during aphid infection. However, these data still demonstrate that the PBS1 ${ }^{\text {TuMV }}$ decoy is capable of conferring strong resistance to TuMV in a natural context.

B
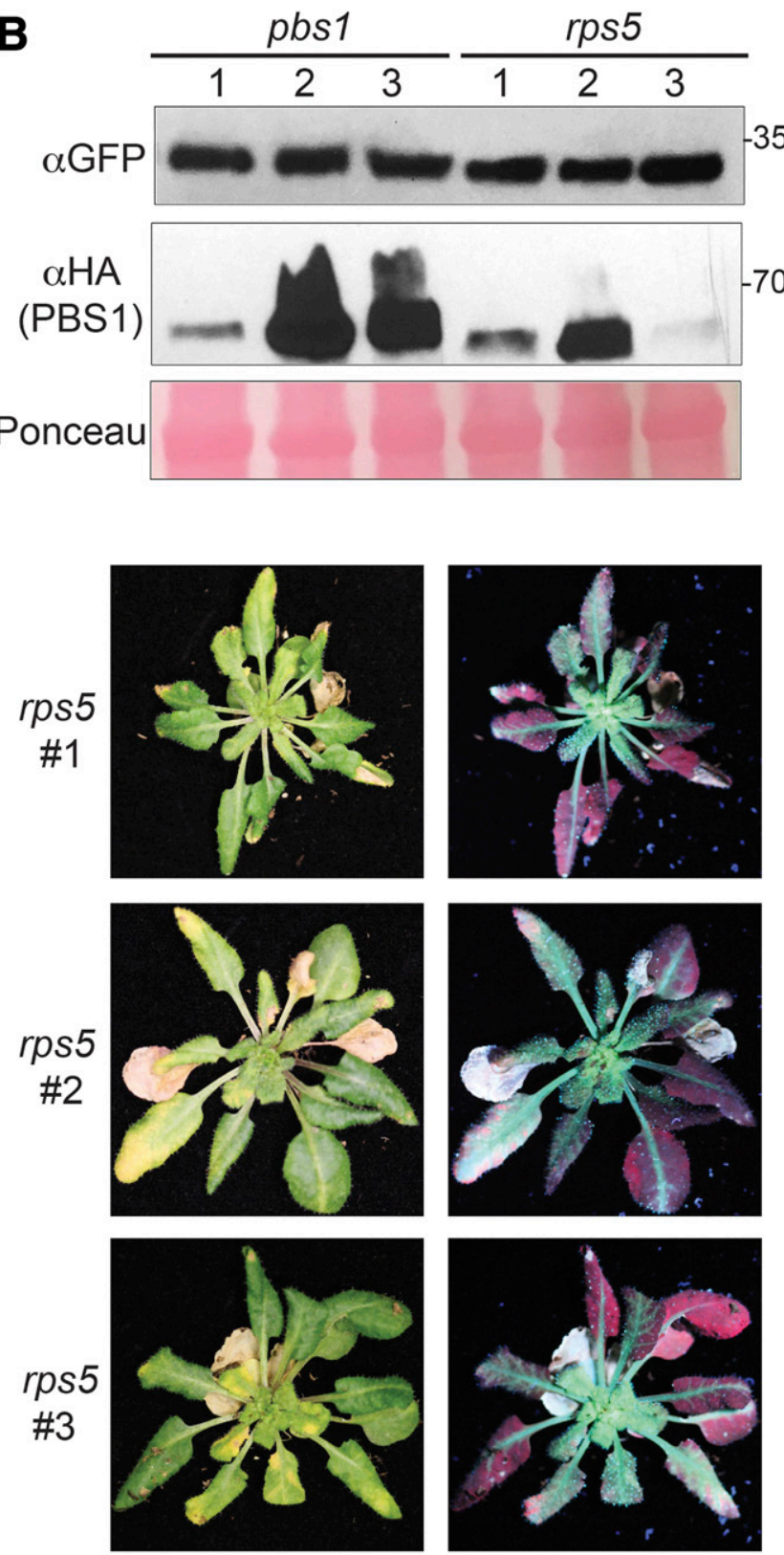

\section{S::6K2-PBS1 $1^{\text {TuMV }}$-HA}

Fig. 4. 6K2-PBS1 ${ }^{\text {TuMV }}$ does not function in transgenic Arabidopsis. A, White light and ultraviolet photographs showing the spread of turnip mosaic virus (TuMV) (6K2-GFP) in three independent 6K2-PBS1 ${ }^{\text {TuMV }}$-transformed homozygous lines in $p b s 1$ and $r p s 5$ mutant backgrounds at 3 weeks postinfection. B, Immunoblots showing 6K2-PBS1 ${ }^{\text {TuMV }}$ and virally produced 6K2-GFP expression levels in the lines pictured in A. 
Overexpression of a soybean PBS1 decoy protein, GmPBS1-1 ${ }^{\text {SMV }}$, in soybean confers immunity to SMV.

We have recently shown that PBS1 proteins from soybean can also be engineered to confer recognition of the NIa protease from SMV and that cleavage of these decoy proteins activates cell death in soybean protoplasts, suggesting the decoy engineering approach can be extended to a crop plant (Helm et al. 2019). It was unclear, however, whether transgenic soybean expressing the GmPBS1-1 ${ }^{\text {SMV }}$ decoy protein would confer resistance to SMV. We thus generated transgenic soybean [Glycine $\max$ (L.) Merr. cultivar Williams 82] constitutively expressing HA-tagged GmPBS1-1 ${ }^{\text {SMV }}$ under an enhanced $35 \mathrm{~S}$ promoter. Three independent T0 soybean plants were obtained. Screening of T1 progeny from each line for expression of $\beta$-glucuronidase (GUS) (discussed below), a marker on the TDNA vector used for transformation, revealed that only one T1 family segregated the T-DNA in a 3:1 ratio. We harvested seed from three sibling $\mathrm{T} 1$ progeny of this line to generate three $\mathrm{T} 2$ families, two of which contained the T-DNA (families A and B) and one of which did not (family C), based on staining for GUS expression and genotyping by PCR. To test for resistance to SMV infection, unifoliate leaves of 12-day-old T2 soybean plants were rub-inoculated with SMV-Nv::GFP virions. After 3 weeks, the third trifoliate leaves were scored for viral

A $35 \mathrm{~S}:: \mathrm{PBS} 1^{\text {TuMV }_{-H A}}$
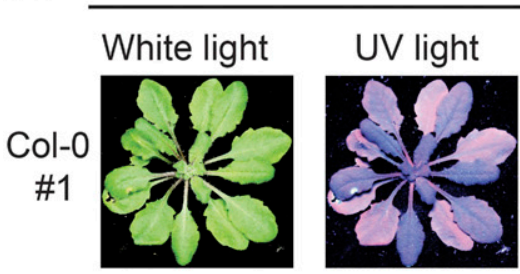

Col-0 \#2
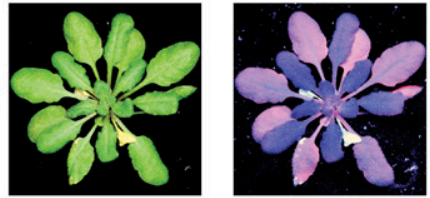

Col-0
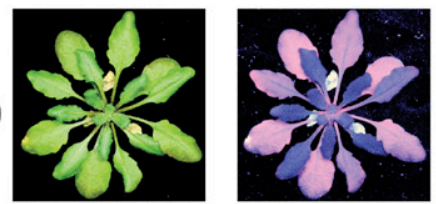

pbs1::PBS1 ${ }^{\text {TuMV }_{-H A}}$

White light

UV light
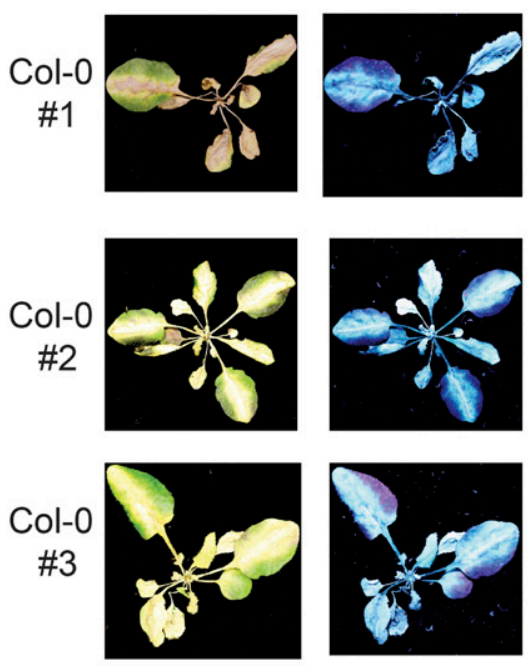

White light UV light

pbs1
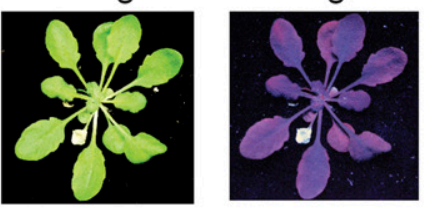

pbs1
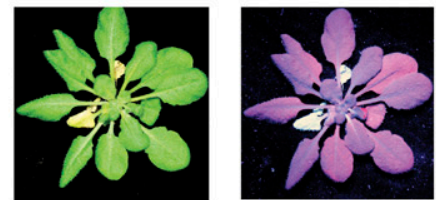

pbs1
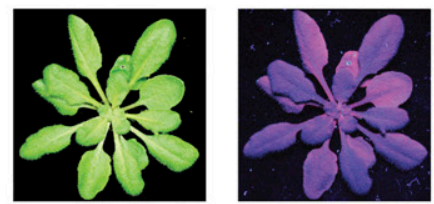

B

pbs1::

PBS1TuMV

\begin{tabular}{|c|c|c|c|c|c|c|c|c|}
\hline$-\mathrm{HA}$ & \multicolumn{8}{|c|}{$35 S:: P B S 1^{T u M V}-H A$} \\
\hline Col-0 & & ,ol-c & & & bs1 & & & os5 \\
\hline 2 & 1 & 2 & 3 & 1 & 2 & 3 & 1 & 2 \\
\hline
\end{tabular}
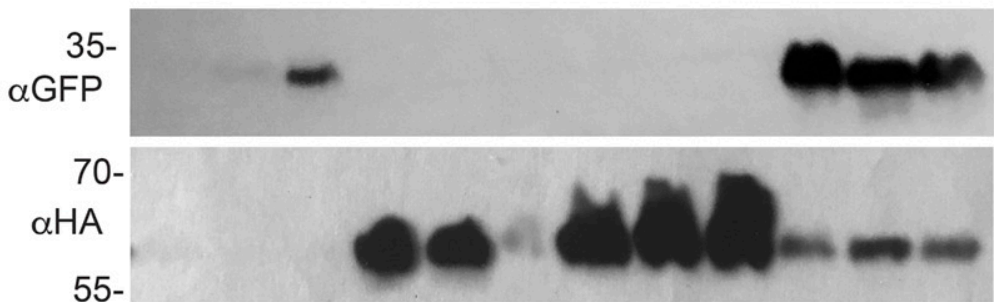

$15 \mathrm{sec}$ exp

rps5

\#3
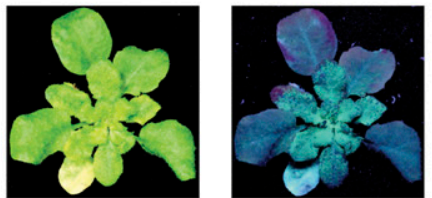
presence under white and ultraviolet light to assess systemic spread of SMV. No observable mosaic symptoms or SMV coat protein $(\mathrm{CP})$ accumulation was seen in families A or B (10 plants each), while seven of 10 family $C$ plants showed virus accumulation (Fig. 8). Consistent with these results, immunoblot analysis revealed that all plants in families $\mathrm{A}$ and $\mathrm{B}$ expressed PBS1-1 ${ }^{\text {SMV }}$, while none of the family C plants showed PBS1 ${ }^{\text {SMV }}$ expression. These data indicate that transgenic overexpression of the GmPBS1-1 ${ }^{\text {SMV }}$ decoy protein confers resistance to systemic infection by SMV without a trailing necrosis phenotype nor any obvious deleterious effects on plant growth.

\section{DISCUSSION}

The above experiments show that the PBS1 decoy system is capable of conferring complete resistance to a viral pathogen.
We have also shown that PM localization is not essential for the stable accumulation of PBS1 ${ }^{\text {TuMV }}$ and RPS5. Although cytosolic RPS5 is unstable, targeting it to other cellular compartments can stabilize it. Likewise, PM localization is not necessary for cleavage of PBS $1^{\text {TuMV }}$ by the TuMV NIa protease. However, our data suggest that RPS5 must be at the PM to signal, even when constitutively active. This finding was somewhat unexpected, as there is a wide variation in the subcellular localization of NLR proteins (Takemoto et al. 2012). For example, the Flax L6 protein localizes to the Golgi apparatus and Arabidopsis RPP1-WsA accumulates in the wider endomembrane system (Takemoto et al. 2012). In fact, it seems the only requirement for the localization of resistance (R) proteins is a colocalization with their cognate effector or guardee or both.

Furthermore, some $\mathrm{R}$ proteins have been shown to retain function after artificial relocalization. For example, relocalizing
EV

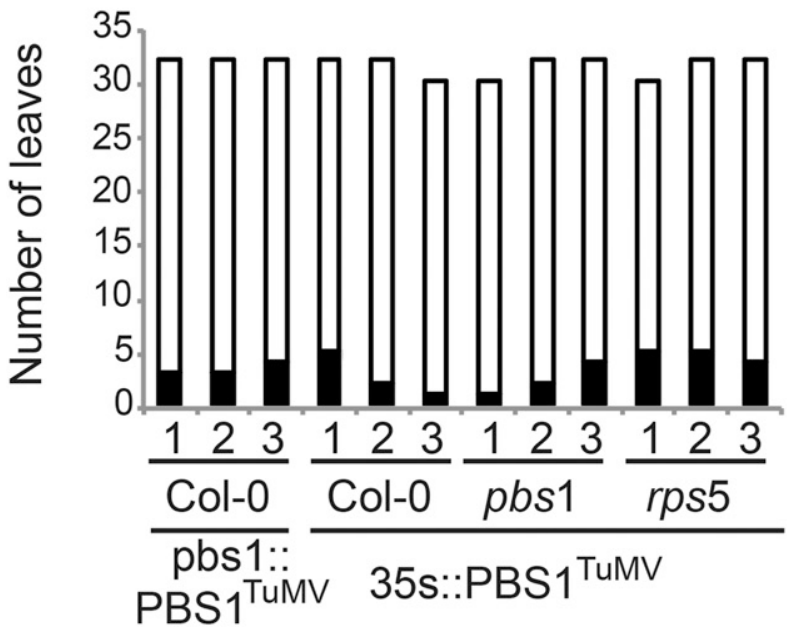

AvrPphB

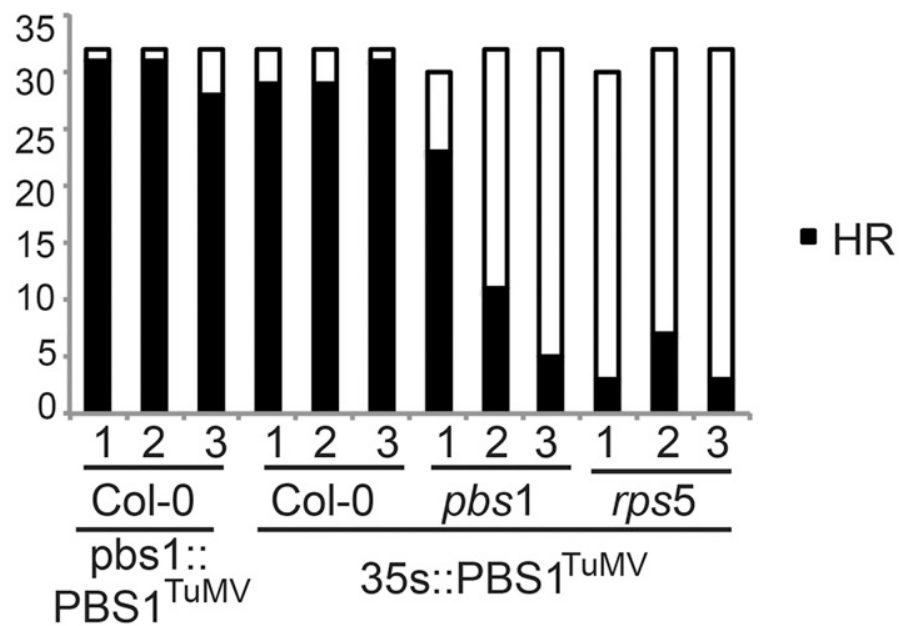

Fig. 6. Arabidopsis expressing both wild-type PBS1 and PBS $1^{\text {TuMV }}$ retain recognition of AvrPphB. Bar charts showing the number of leaves expressing a hypersensitive response (HR) phenotype in response to infiltration with Pseudomonas syringae expressing either AvrPphB or an empty vector. Bar height represents the number of leaves infiltrated. The black bar represents the number of leaves expressing cell death. HR tests were done in 4-week-old homozygous $35 \mathrm{~S}: \mathrm{PBS}^{\text {TuMV }}$ transformants in Col-0, pbs1, and rps5 backgrounds and pbs1::PBS1 ${ }^{\text {TuMV }}$ in Col-0.

A $\quad$ B

\begin{tabular}{|c|c|}
\hline Line & Infected plants \\
\hline WT Control & $11 / 27$ \\
\hline Col-0 \#1 & $0 / 10$ \\
\hline Col-0 \#2 & $0 / 10$ \\
\hline Col-0 \#3 & $2 / 10$ \\
\hline$p b s 1 \# 1$ & $0 / 10$ \\
\hline$p b s 1 \# 2$ & $0 / 10$ \\
\hline$p b s 1 \# 3$ & $0 / 10$ \\
\hline rps5 $\# 1$ & $1 / 10$ \\
\hline$r p s 5 \# 2$ & $3 / 9$ \\
\hline$r p s 5 \# 3$ & $3 / 10$ \\
\hline
\end{tabular}

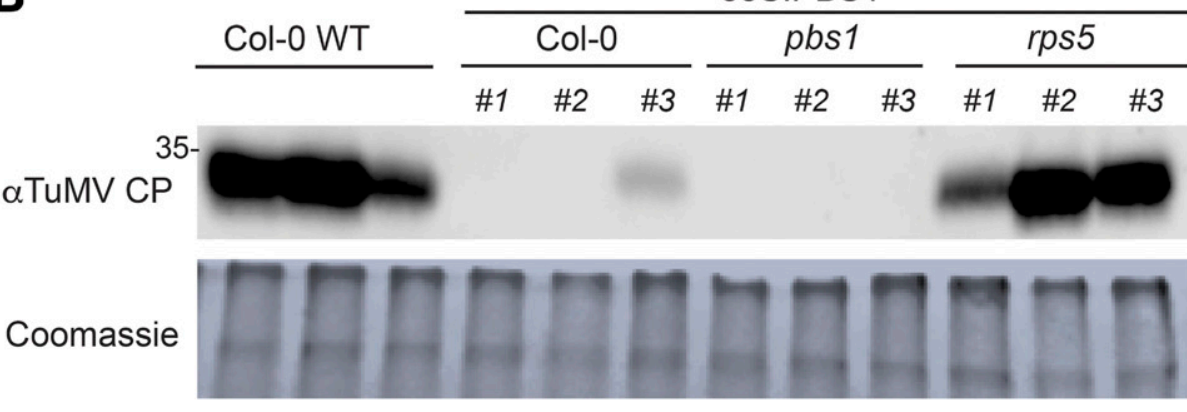

$\alpha \mathrm{HA}$

(PBS1)

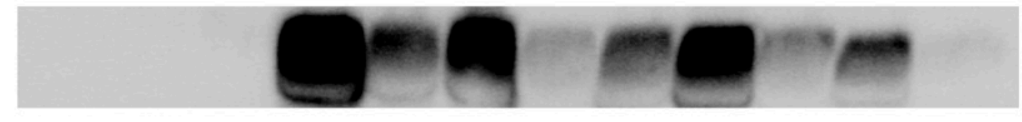

Coomassie

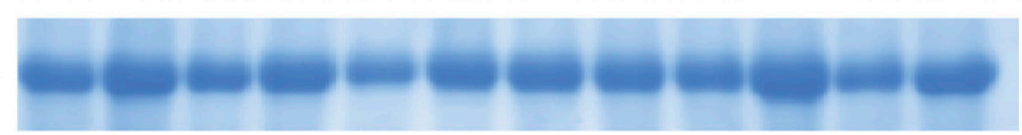

Fig. 7. Aphid transmission of turnip mosaic virus (TuMV) is blocked in PBS1 $1^{\text {TuMV }}$ overexpressing lines. A, The percentage of Arabidopsis plants expressing green fluorescent protein as a result of TuMV infection in Col-0, pbs1, and rps5 backgrounds at 15 days after aphid inoculation. B, Immunoblots showing $\mathrm{PBS}^{\mathrm{TuMV}}$ and TuMV coat protein expression levels in the lines represented in A. 
the L6 protein from the Golgi to the tonoplast does not impair its function (Takemoto et al. 2012). Similarly, it is known that disease resistance proteins such as MLA10 and Rx naturally relocate from the cytosol to the nucleus upon activation (Shen et al. 2007; Slootweg et al. 2010). This shift in location is essential for MLA10 signaling, allowing it to interact with transcriptional activators and repressors to produce a defense response (Chang et al. 2013). For Rx, however, activation and signaling take place in the cytoplasm, and nuclear accumulation appears to represent a form of negative regulation (Tameling et al. 2010). Previous work has shown that RPS5 localization does not change after activation (Qi et al. 2012). However, it is known that changes in gene expression are required for $R$ gene-mediated HR (He et al. 1994; Keen et al. 1981); thus, there must be some kind of signal that is transmitted to the nucleus following the activation of RPS5 at the PM.

The stringent requirement of RPS5 to be at the PM may, therefore, reflect the presence of a PM-localized partner that is activated along with RPS5 and performs a signaling function. NLR helpers are relatively common. The Nicotiana tabacum NLR protein $\mathrm{N}$ requires an interaction with a second NLR protein, named NRG1, to confer resistance to tobacco mosaic virus. Similarly, various ADR1 family proteins in Arabidopsis function as helper NLRs performing signaling functions necessary for resistance (Bonardi et al. 2011; Peart et al. 2005). Significantly, the immune functions of ADR1-L2 are unaffected by P-loop mutations that inhibit the nucleotide exchange necessary for canonical $\mathrm{R}$ protein activation (Bonardi et al. 2011). It has been suggested that this could represent an as-yet-unknown mechanism of NLR signaling used by many Arabidopsis NLRs. Such a mechanism could be analogous to that used by $\mathrm{Pb} 1$, a coiled coil (CC)-NLR from rice that lacks the canonical P-loop motif (Bonardi et al. 2012, Hayashi et al. 2010).

While RPS5 appears to function as a singleton, the possibility of a signaling partner or several redundant partners must be considered. If such partners exist, they must function independently of PBS1, because autoactive RPS5 ${ }^{\mathrm{D} 266 \mathrm{E}}$ can cause
HR when transiently expressed alone in $N$. benthamiana (Ade et al. 2007). This observation also indicates that any RPS5 signaling partner or partners would have to be conserved between Arabidopsis and $N$. benthamiana and would likely be located at the PM, as a cytoplasmic partner would be able to associate with RPS5 when localized to other cellular compartments. It is plausible that such a putative signaling partner could act as a base for the formation of a higher-order signaling complex with RPS5, as happens with the NLR proteins NLRC4 and NAIP2 in the activation of the mammalian inflammasome (Hu et al. 2015) or as has been proposed for the Arabidopsis ADR1 proteins (Bonardi et al. 2012).

Alternatively, if RPS5 activates cell-death signaling via a mechanism similar to that proposed for ZAR1, it may not require a signaling partner. ZAR1 oligomerizes upon activation and associates with the PM via hydrophobic residues on the surface of the first barrel of its CC domain (Wang et al. 2019). Computational analyses show that these residues within the CC domain of ZAR1 are part of a conserved motif, the MADA motif, which is shared with approximately $20 \%$ of the CCNLRs in Arabidopsis. The MADA motif is thought to be required for oligomerization and membrane association (Adachi et al. 2019; Wang et al. 2019). Oligomerized ZAR1 is then predicted to insert into the PM to form a pore that could act as a calcium channel. The resulting calcium influx would then lead to gene activation and cell death (Wang et al. 2019). This model is intriguing, as it is known that calcium signaling is one of the first events triggered by effector recognition. Calcium channel blockers, such as $\mathrm{LaCl}$, can inhibit the HR induced by other PM-localized NLR proteins, such as RPM1 (Grant et al. 2000). The nature of the calcium burst is also fine-tuned to the pathogen that elicits it, suggesting a close tie between calcium response and pathogen recognition (Grant et al. 2000).

However, the N-terminal alpha helix of ZAR1 is not conserved in RPS5. RPS5 lacks both the MADA motif and the residues shown to be necessary for ZAR1 oligomerization. Together, this suggests that RPS5 may not form a funnel-shaped structure to associate with the PM upon activation and, instead,
A

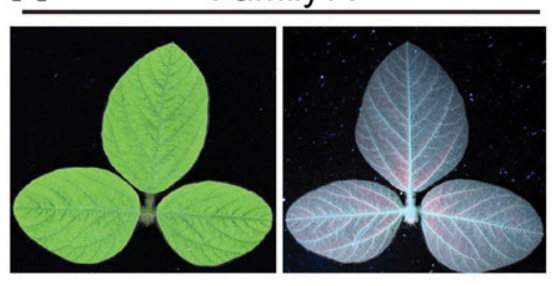

Family A
Family B

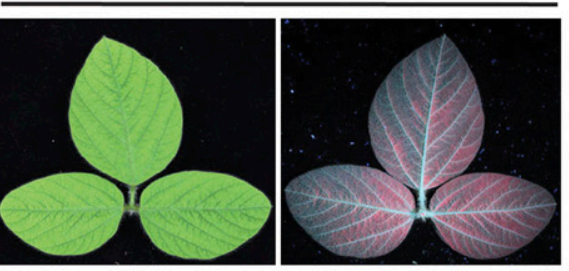

Family C

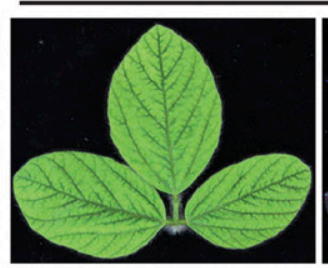

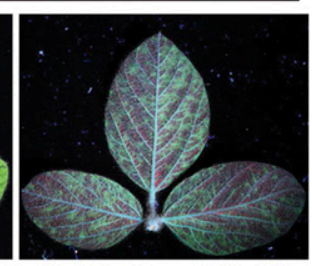

B

SMV-Nv::GFP

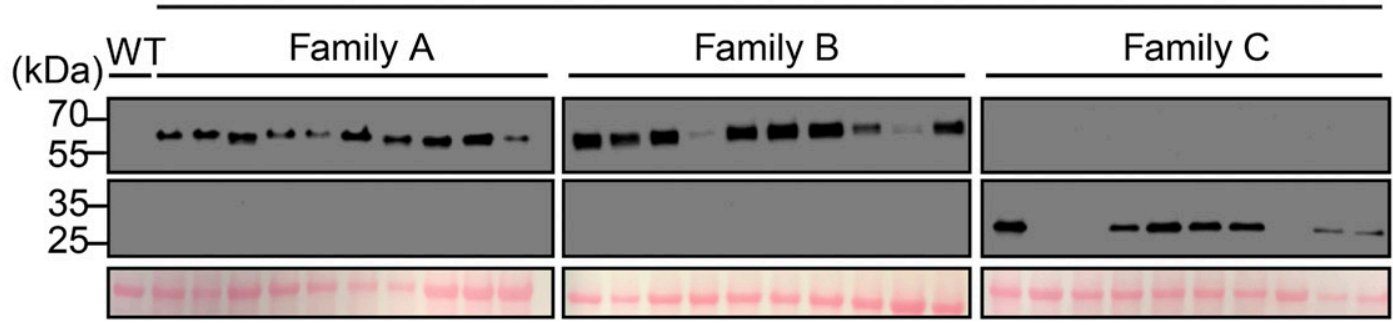

a-HA (GmPBS1-1 ${ }^{\text {SMV }}$ )

$\alpha-S M V-C P$

RUBISCO

Fig. 8. Overexpression of GmPBS1-1 ${ }^{\mathrm{SMV}}$ in soybean confers resistance to soybean mosaic virus (SMV). A, White light and ultraviolet light photographs of soybean third trifoliate leaves from three sibling T3 families rub-inoculated with SMV-Nv::GFP virions on their unifoliate leaves 3 weeks prior. Family C lacks the $P B S 1-1^{S M V}$ transgene. White light images of adaxial sides (left) show SMV symptoms. Ultraviolet images of abaxial sides (right) show SMV accumulation, as indicated by green fluorescence. B, Immunoblots of soybean trifoliate leaves from 10 individual plants from each family, showing GmPBS1-1 ${ }^{\text {SMV }}$ expression (top), SMV coat protein (middle), and Ponceau stain of RUBISCO (bottom). Uninfected nontransgenic Williams 82 (wild type [WT]) was used for a negative control to show antibody specificity. 
may function through a different signaling mechanism. RPS5 appears to be more closely related to the G10 NLRs. This group is localized to the PM and, despite lacking the MADA motif, their CC domains are still capable of producing a cell-death response when expressed in $N$. benthamiana (Lee et al. 2020). It is interesting to note, however, that the CC domain of RPS5 does not cause an HR when transiently expressed in the same manner (Qi et al. 2012), suggesting that it may function through yet another PM-localized signaling mechanism.

Elucidating the signaling mechanism used by RPS5 would shed light on whether the direct pore mechanism proposed for ZAR1 is a common signaling mechanism used by CC-NLRs or whether the scaffolding mechanism used by mammalian NLRs is also present in plants. In either case, it could be that the signaling machinery used by RPS5 is a general mechanism used by other NLR proteins, like RPM1, that also do not relocalize upon activation (Gao et al. 2011).

The experiments above have shown that overexpression of PBS1 $1^{\text {TuMV }}$ is capable of alleviating the trailing necrosis phenotype seen previously (Kim et al. 2016). This lends support to the correlation seen by Kim et al. (2016) between the expression levels of PBS $1^{\text {TuMV }}$ and the corresponding severity of trailing necrosis. It is noteworthy that overexpression of PBS $1^{\text {TuMV }}$ did not cause observable changes in plant growth, which suggests that overexpression does not cause constitutive activation of defense responses or other deleterious effects. Furthermore, as the recognition of AvrPphB remained unaffected in lines expressing both PBS $1^{\text {TuMV }}$ and WT PBS1, it may be possible to express multiple PBS1 decoys in a single plant, further expanding the recognition specificity of RPS5.

The PBS1/RPS5 decoy system should be capable of conveying immunity to any biotrophic pathogen that requires a protease as part of its infection or replication machinery, providing that the protease accumulates inside the host cell and recognizes a cleavage sequence of seven or fewer amino acids. This has the potential to be broadly applicable, as bacterial, viral, and fungal pathogens as well as oomycetes and nematodes, are known to secrete proteases as part of their infection cycle (Alfano and Collmer 2004; Gardner et al. 2018; Lim et al. 2011; Orbach et al. 2000; Raffaele et al. 2010; Zhang et al. 2020). We expect that at least of some of these are translocated into host cells. Indeed, one of the first fungal avirulence proteins identified, AVR-Pita, from the rice blast fungus Magnaportha oryzae is predicted to function as a metalloprotease (Orbach et al. 2000). AVR-Pita is recognized by the NLR protein Pi-ta (Jia et al. 2000), which indicates that AVR-Pita is being translocated into host cells.

Finally, we have also shown that the PBS1 decoy system has the potential to be transferred to crop plants without the need to transfer AtRPS5. We have previously shown that insertion of an NIa cleavage site in soybean PBS1 proteins enables their cleavage by the NIa protease from SMV (Helm et al. 2019). Significantly, coexpression of a decoy soybean PBS1 protein with the SMV NIa protease triggers cell death in soybean protoplasts (Helm et al. 2019). Our finding that transgenic overexpression of a soybean PBS1 decoy can confer complete resistance to SMV confirms that the PBS1 decoy approach can be deployed in crops using PBS1 genes endogenous to each crop species.

PBS1 is highly conserved in both dicots and monocots (Caldwell and Michelmore 2009; Swiderski and Innes 2001), and many crop species are already resistant to Pseudomonas syringae through the recognition of AvrPphB, suggesting that they possess a functional analog of RPS5 (Carter et al. 2019; Russell et al. 2015). Indeed, we have recently shown that soybean, barley, and wheat all respond to AvrPphB protease activity (Carter et al. 2019; Helm et al. 2019) and this response in barley is mediated by a disease resistance protein designated
Pbr1 (Carter et al. 2019). Barley contains two PBS1 orthologs, both of which are cleaved by AvrPphB, and it is interesting to note that, while Pbr1 appears to monitor barley PBS1 orthologs in a way that is analogous to RPS5, RPS5 and Pbr1 are not orthologous (Carter et al. 2019). This suggests that the R protein involved in AvrPphB recognition has evolved convergently across species, whereas PBS1, the target of AvrPphB, appears to remain the same.

This highlights the usefulness of PBS1 as a modifiable decoy, as it is identifiable across flowering plant species even in the absence of RPS5 (Caldwell and Michelmore 2009) and is consistently a guarded target of AvrPphB. Thus, it should be feasible to engineer novel disease resistance traits in crops simply by making minor modifications to endogenous PBS1 genes using genome-editing approaches. Furthermore, in crops such as soybean and wheat, which have three or more PBS1 coorthologs, it should be possible to use genome editing to create multiple different PBS1 decoys that target different pathogens or that target multiple proteases in a single pathogen to enhance durability.

\section{MATERIALS AND METHODS}

\section{Plant growth.}

Nicotiana benthamiana and Arabidopsis thaliana plants were grown under a 12 -h light and 12 -h dark cycle at $24^{\circ} \mathrm{C}$ in Pro-Mix PGX Biofungicide plug and germination mix supplemented with Osmocote 14-14-14 slow release fertilizer (Scotts).

Seeds of soybean [Glycine $\max (\mathrm{L}$.) Merr.] cultivars Williams 82 and Williams $82 P B S 1-1^{S M V}$ transgenic lines were sown in clay pots containing greenhouse soil (generated by composting plants and previously used potting mix and then supplementing with small amounts of sand, perlite, and vermiculite) supplemented with Osmocote slow-release fertilizer (14-14-14) and grown in a growth chamber under a 16-h light amd 8-h dark photoperiod at $23^{\circ} \mathrm{C}$ with average light intensities of 300 $\mu$ Einsteins $\mathrm{m}^{-2} \mathrm{~s}^{-1}$ (at soil height).

\section{Generation of plant expression constructs.}

For the nuclear constructs, the RPS5 (AT1G12220) and PBS1 ${ }^{\text {TuMV }}$ (based on PBS1 AT5G13160) open reading frames were amplified from plasmids described by Ade et al. (2007) and Kim et al. (2016), respectively, using PCR with primers that incorporated attB sites to enable Gateway-based cloning (Supplementary Table S1). In addition, the forward primers were designed to eliminate the native acylation motifs of PBS1 and RPS5. For NLS constructs, an NLS sequence (Gao et al. 2011) was incorporated into the forward primer. The $6 \mathrm{~K} 2-$ PBS1 ${ }^{\text {TuMV }}$ construct was made through splicing overlap extension (SOE) PCR (Bryksin and Matsumura 2010). Separate PCR amplifications were performed to generate TuMV $6 \mathrm{~K} 2$ and PBS $1^{\text {TuMV }}$ fragments with the addition of attB sites at the $5^{\prime}$ end of the $6 \mathrm{~K} 2$ sequence and the $3^{\prime}$ end of the PBS1 sequence for later cloning. The reverse primer of the $6 \mathrm{~K} 2$ sequence included sequence that overlapped with the PBS1 sequence, which enabled joining of the two fragments via SOE PCR. The 6K2-RPS5 construct was produced by modifying an existing RPS5-5xMYC construct, as described by Ade et al. (2007), via In-Fusion cloning (Clontech) to fuse the $6 \mathrm{~K} 2$ fragment (GenBank D10927.1) to the N-terminus of RPS5. The resulting 6K2-RPS5-5xMYC construct (in plasmid pTA7001DEST [Gu and Innes 2011]) was subjected to another round of PCR to isolate the 6K2-RPS5 fragment with the addition of attB sites for later cloning. The purified PBS $1^{\text {TuMV }}$ and RPS5 fragments containing attB sites and NLS/6K2 localization sequences were incorporated into pBSDONR-P1P4 using BP 
recombinase (Invitrogen). The cytoplasmic $\mathrm{PBS} 1^{\mathrm{TuMV}}$ was made by mutating an existing cytoplasmic PBS1 construct in pBSDONR P1P4, as described by Qi et al. (2014) to insert the TuMV NIa protease consensus cleavage site. The cytoplasmic RPS5 construct was previously detailed by Qi et al. (2012). The C-terminal RPS5-NLS construct was generated through the addition of the NLS sequence to the C-terminus of the cytoplasmic construct. Constructs were recombined into the dexamethasone-inducible vector pBAV154 (Vinatzer et al. 2006), using multisite Gateway recombination cloning to add a sYFP tag for confocal microscopy and either a $3 \times \mathrm{HA}$ tag, in the case of PBS1 ${ }^{\text {TuMV }}$, or a $5 \times$ MYC tag, in the case of RPS5, for immunoblotting and cell-death assays. Constructs were confirmed via sequencing before being transformed into Agrobacterium tumefaciens GV3101 (pMP90). To generate the 35S:PBS $1^{\text {TuMV }}$ construct, PBS $1^{\text {TuMV }}$ in pBSDONR P1P4 and a C-terminal $3 \times$ HA tag were recombined into the destination vector pEG100 (Earley et al. 2006), using LR clonase. The TuMV (6K2:GFP) construct was previously described by Wan et al. (2015). All primers used are shown in Supplementary Table S1.

To generate the pWI-1000:E35S::GmPBS1-1 ${ }^{S M V}-H A$ construct, GmPBS1-1 $1^{S M V}-H A$ was PCR-amplified from the pBAV154:GmPBS1-1 ${ }^{S M V}$-HA template (Helm et al. 2019), using primers designed to introduce $X b a \mathrm{I}$ restriction sites at each end. The resulting PCR products were gel-purified using the QIAquick gel extraction kit (Qiagen) and were cloned into the XbaI site of pWI-1000 (M. Peterson, Wisconsin Crop Innovation Center). The resulting constructs were sequenceverified to check for proper sequence and reading frame.

\section{Generation of transgenic Arabidopsis lines.}

The 35S:6K2-PBS1 ${ }^{\text {TuMV }}$-3xHA transgenic Arabidopsis lines were created by transferring the $6 \mathrm{~K} 2-\mathrm{PBS} 1^{\text {TuMV }}$ construct in pBSDONR P1P4 (Gu and Innes 2011) into pEG100 along with a 3xHA tag, using multisite Gateway cloning. The resulting construct was confirmed via sequencing before being transformed into Agrobacterium tumefaciens GV3101 (pMP90). This strain was then used to prepare floral dips of Arabidopsis rps 5 and pbs 1 knockout lines, SALK lines 127201 and 062464, respectively (Clough and Bent 1998). Progeny were selected via BASTA resistance in $\mathrm{T} 1$ and $\mathrm{T} 2$ generations, and then, homozygous T3 families were identified. The same process was followed for the creation of $35 \mathrm{~S}: \mathrm{PBS}^{\text {TuMV }}-3 \times \mathrm{HA}$ lines. The pbs $1::$ PBS $1^{\text {TuMV }}-3 \times$ HA lines were described previously (Kim et al. 2016).

\section{Generation of transgenic soybean lines and infection with SMV.}

Transgenic Williams 82 soybean lines were generated by the Wisconsin Crop Innovation Center using an Agrobacteriummediated transformation protocol and T1 seed from three independent T0 plants were obtained from the Wisconsin Crop Innovation Center. T1 plants were assessed for expression of a GUS marker gene present on the T-DNA of the pWI-1000 vector, using X-gluc staining of unifoliate leaves (Jefferson et al. 1987). T1 plants were selfed to obtain T2 seed. T2 plants were grown in a growth chamber at $22^{\circ} \mathrm{C}$ under a 16 -h day (300 $\mu$ Einsteins $\left.\mathrm{m}^{-2} \mathrm{~s}^{-1}\right)$. Unifoliate leaves of 12-to 14-day-old plants were rub-inoculated with plasmid DNA encoding fulllength SMV-NV::GFP (T1 plants) or SMV virions prepared from infected soybean plants (T2 plants), as described by Helm et al. (2019). In brief, virions were obtained from previously infected WT Williams 82 plants rub-inoculated with infectious pSMV-Nv:GFP plasmid DNA and were maintained after infection for 4 weeks in a growth chamber. Heavily infected trifoliate leaves were harvested in $1 \times$ phosphate-buffered saline
(137 mM NaCl, $2.7 \mathrm{mM} \mathrm{KCl,} 10 \mathrm{mM} \mathrm{Na} \mathrm{HPO}_{4}, 1.8 \mathrm{mM}$ $\mathrm{KH}_{2} \mathrm{PO}_{4}$, pH 7.4), with cell debris cleared by centrifugation, and the supernatant containing virions was stored at $-80^{\circ} \mathrm{C}$ until use. Soybean plants were grown in a growth chamber until unifoliate leaves were fully expanded (approximately 12 to 14 days after planting). The abaxial side of a unifoliate leaf was wounded with Carborundum and, using a cotton swab, virion suspension was applied to the wound. Plants were then returned to the growth chamber for 3 weeks. Third trifoliate leaves were harvested when completely expanded (approximately 21 days postinoculation) and were photographed under white and ultraviolet light. Tissue was flash-frozen in liquid nitrogen and stored at $-80^{\circ} \mathrm{C}$.

\section{Transient protein expression.}

Agrobacterium cells were taken from Luria Bertani plates and were suspended in $10 \mathrm{mM} \mathrm{MgCl}_{2}$ with $100 \mu \mathrm{M}$ acetosyringone (Sigma-Aldrich). After a $2-\mathrm{h}$ incubation at room temperature, bacterial cultures were infiltrated into the leaves of 3 - to 4-week-old $N$. benthamiana with a needleless syringe. For microscopy and HR, the final concentration of infiltrated bacteria, once mixed, was an optical density at $600 \mathrm{~nm}\left(\mathrm{OD}_{600}\right)$ of $0.3 \pm 0.01$ and, for immunoblot analyses, $0.15 \pm 0.01$.

\section{TuMV infection.}

Agrobacterium cells containing pCAMBIA carrying TuMV(6K2-GFP) (Wan et al. 2015) were taken from plates and were suspended to an $\mathrm{OD}_{600}$ of 0.1 in $10 \mathrm{mM} \mathrm{MgCl}_{2}$ with $100 \mu \mathrm{M}$ acetosyringone (Sigma-Aldrich). After a 2-h incubation at room temperature, bacterial cultures were infiltrated into 3-week-old Arabidopsis leaves with a needleless syringe. Infection was allowed to progress for 3 weeks before being photographed under white and ultraviolet light.

\section{Fluorescence microscopy.}

At $48 \mathrm{~h}$ after infiltration, plants were sprayed with $50 \mu \mathrm{M}$ dexamethasone, $0.02 \%$ Tween 20 and, at $24 \mathrm{~h}$ post-transgene induction, leaves were imaged, using a Leica SP5 scanning confocal light microscope and an HCX PL APO CS $63 \times 1.2$ objective, pinhole $99.90 \mu \mathrm{M}$. Each construct was imaged at least three times, each from separate infiltration events.

\section{Immunoblots.}

For transient assays in $N$. benthamiana, $48 \mathrm{~h}$ after infiltration, plants were sprayed with $50 \mu \mathrm{M}$ dexamethasone. At $6 \mathrm{~h}$ posttransgene induction, samples are taken for protein extraction. For assays in Arabidopsis, whole plant samples were taken immediately after TuMV symptoms were photographed. For samples in $N$. benthamiana, leaves were pooled from two to three plants. Leaf tissue was ground in extraction buffer (150 mM NaCl, $50 \mathrm{mM}$ Tris [pH 7.5], 0.2\% Nonidet P-40 [Sigma-Aldrich], $1 \%$ plant protease inhibitor cocktail [SigmaAldrich], $2 \mathrm{mM}$ 2,2'-dipyridyl disulfide). Cell debris was pelleted at $8,000 \times g, 4^{\circ} \mathrm{C}$, for $10 \mathrm{~min}$, and the collected supernatants were separated on a 4 to $20 \%$ Tris-glycine stain free polyacrylamide gel (BioRad) at $185 \mathrm{~V}$ for $1 \mathrm{~h}$ in $1 \times$ Tris/glycine/sodium dodecyl sulfate (SDS) running buffer. Total proteins were transferred to nitrocellulose membrane (GE Water and Process Technologies). Membranes were blocked overnight at $4^{\circ} \mathrm{C}$ in $5 \%$ milk. Proteins were subsequently detected with horseradish peroxidase (HRP)-conjugated anti-HA antibody (rat monoclonal; Roche) or mouse monoclonal antiGFP antibody (Novus Biologicals). Membranes were washed three times for $15 \mathrm{~min}$ in $1 \times$ Tris-buffered saline (TBS) with $0.1 \%$ Tween 20 (TBST) and were incubated with HRPconjugated goat antimouse antibody (Abcam). All antibodies were used at a concentration of 1:5,000. The nitrocellulose 
membranes were washed three times for $15 \mathrm{~min}$ in TBST and were imaged using Supersignal West Femto maximum sensitivity substrates (Thermo Scientific) and X-ray film. The experiment was repeated three times.

For protein extraction from soybean, trifoliate leaves were ground to a powder under liquid nitrogen with a mortar and pestle. Three times the volume of ice cold IP buffer $(50 \mathrm{mM}$ Tris- $\mathrm{HCl}, 150 \mathrm{mM} \mathrm{NaCl}, 10 \%$ glycerol, $1 \mathrm{mM}$ diothioreitol, $1 \%$ NP-40, $0.1 \%$ Triton X-100, $1 \%$ plant protease inhibitor cocktail, $1 \%$ 2,2'-dipyridyldisulfide, 1 mM EDTA) was added to the powder and the mixture was ground until homogenous. Leaf extracts were centrifuged $2 \times$ at $12,500 \times g$ at $4^{\circ} \mathrm{C}$, and supernatants free of plant tissue debris were collected. Cleared supernatant $(500 \mu \mathrm{l})$ was added to $10 \mu \mathrm{l}$ anti-HA magnetic beads (MedChemExpress) and was incubated on a rotator at $4^{\circ} \mathrm{C}$ for $3 \mathrm{~h}$. Immunoprecipitation samples were collected on a magnetic stand for $5 \mathrm{~min}$ and unbound protein lysate was removed and was saved for SMV CP analysis. Magnetic beads were washed five times in ice cold IP buffer. Protein was eluted in $40 \mu \mathrm{l}$ of IP buffer and $10 \mu \mathrm{l}$ of $5 \times$ SDS-polyacrylamide gel electrophoresis (PAGE) buffer. Samples were boiled at $95^{\circ} \mathrm{C}$ for $5 \mathrm{~min}$ and were returned to the magnetic stand to separate sample from magnetic beads. A volume of $10 \mu \mathrm{l}$ was loaded onto a 4 to $20 \%$ SDS-PAGE gel. Unbound protein lysate $(40 \mu \mathrm{l})$ was added to $10 \mu \mathrm{l}$ of $5 \times$ SDS-PAGE loading buffer and was boiled at $95^{\circ} \mathrm{C}$ for $5 \mathrm{~min}$. Samples were briefly centrifuged and $10 \mu \mathrm{l}$ of sample was loaded onto A 4 to $20 \%$ SDS-PAGE gel. Gels were run for approximately $1 \mathrm{~h}$ at $160 \mathrm{~V}$ and were transferred to nitrocellulose membranes at $300 \mathrm{amps}$ for $1 \mathrm{~h}$. Membranes with unbound protein lysates were stained with Ponceau for $3 \mathrm{~min}$, were rinsed with deionized water, and were photographed for RUBISCO loading control.

SMV CP immunoblots were blocked overnight with 5\% dry milk in $1 \times$ Tris-buffered saline (TBS; $50 \mathrm{mM}$ Tris- $\mathrm{HCl}$, $150 \mathrm{mM} \mathrm{NaCl}, \mathrm{pH}$ 7.5) solution containing TBST, and then, anti-SMV CP antisera (rabbit polyclonal, a gift from S. Tolin) was added at a dilution of 1:20,000 and was incubated at room temperature with gentle shaking for $1 \mathrm{~h}$. Membranes were washed three times with TBST, after which secondary goat antirabbit antibody conjugated to HRP (Abcam) was added at a dilution of 1:5,000 and was incubated at room temperature for 1 $\mathrm{h}$, followed by washing three times with TBST. Anti-HA immunoblots were prepared in a similar fashion, but using an antiHA HRP-conjugated antibody (rat monoclonal; Roche) at 1: 5,000 , with incubation at room temperature for $1 \mathrm{~h}$.

Immunblots were developed using equal parts of Clarity Western ECL substrate peroxide solution and luminol/enhancer solution (BioRad), with incubation at room temperature for 5 min. Immunoblots were imaged using the chemiluminescent setting on the KwikQuant Imager (Kindle Biosciences, LLC).

\section{Cell-death assays in $N$. benthamiana.}

At $48 \mathrm{~h}$ after agrobacterium infiltration into $N$. benthamiana leaves, plants were sprayed with $50 \mu \mathrm{M}$ dexamethasone, and $24 \mathrm{~h}$ later, the infiltrated leaves were assessed for cell death and were photographed under white light. Ten leaves from four to six plants were tested for every treatment in the experiment and the experiment was replicated three times.

\section{Cell-death assays in Arabidopsis.}

Pseudomonas syringae DC3000 expressing either AvrPphB or an empty vector (Simonich and Innes 1995) were subcultured from plates into $10 \mu \mathrm{M} \mathrm{MgCl}$, were syringeinfiltrated into leaves of 4-week-old Arabidopsis, and $24 \mathrm{~h}$ later, the infiltrated leaves were assessed for cell death and were photographed under white light.

\section{Aphid vector assays.}

Nonviruliferous aphid clones of a tobacco-adapted strain of Myzus persicae were reared under controlled conditions $\left(23^{\circ} \mathrm{C}\right.$ with a photoperiod of 12-h days and 12-h nights) on tobacco (Nicotiana tabacum). Adult aphids were transferred to Col0 leaves infected with TuMV (6k2-GFP) for a 10-min acquisition period. After virus acquisition, two aphids were transferred to a 20-day-old plantlet for each treatment for a 24-h inoculation period. After inoculation, the aphids were removed from the plants. Two weeks later, the number of infected plants was recorded for each line, using a hand-held ultraviolet light to visualize GFP, and tissue was collected for immunoblot confirmation. Seven to 10 plants were inoculated per plant line.

For immunoblots of aphid-treated plants, $10 \mathrm{mg}$ of leaf tissue was collected from each plant and was pooled for each line. Leaf tissue was immediately frozen in liquid nitrogen and was ground to a fine powder in a $1.5-\mathrm{ml}$ tube, using steel beads and a paint shaker. Lysis buffer $(1 \mathrm{ml}$ of $0.5 \mathrm{M}$ sodium citrate, $0.5 \mathrm{~g}$ of SDS powder, $0.2 \mathrm{ml}$ of $\beta$-meracptoethanol, $1 \mathrm{ml}$ of $1.5 \mathrm{M} \mathrm{NaCl}$, $7.8 \mathrm{ml}$ of water, 1 tablet of EDTA-free Complete protease inhibitor cocktail) was added directly to the frozen tissue and was mixed until homogeneous at room temperature (1 $\mathrm{mg}$ of tissue: $2 \mu \mathrm{l}$ of buffer). After mixing, samples were boiled for $10 \mathrm{~min}$ and cell debris was pelleted in a microfuge at 15,000 rpm for $10 \mathrm{~min}$ at room temperature. Supernatants were mixed with loading buffer in a $1: 1$ ratio before separation at $70 \mathrm{~V}$ for $15 \mathrm{~min}$, then $90 \mathrm{~V}$ for $1.5 \mathrm{~h}$ on a $10 \%$ Tris-glycine gel (Biorad) in $1 \times$ Tris/glycine/SDS running buffer. Total proteins were transferred to a nitrocellulose membrane and were blocked overnight at $4{ }^{\circ} \mathrm{C}$. Proteins were detected with anti-TuMV CP antibody at a concentration of 1:1500 and goat anti-rabbit immunoglobulin $\mathrm{G}(\mathrm{H}+\mathrm{L})-\mathrm{HRP}$ conjugate (Miltenyi Biotec) at a concentration of $1: 10,000$ or using HRP-conjugated anti-HA antibody (Miltenyi Biotec) at a concentration of 1:2,000. The nitrocellulose membranes were washed three times for 5,15 , and $10 \mathrm{~min}$ in TBST ( $1 \times$ TBS, $0.3 \%$ Tween) and were imaged using a 1:4 ratio of Supersignal West Femto maximum sensitivity substrates and Supersignal West Pico Plus (Thermo Scientific) and a ChemiDoc imaging system (Biorad). Gels were stained with Coommassie blue (0.5 g of Coommassie R250, $200 \mu \mathrm{l}$ of met hanol, $50 \mu \mathrm{l}$ of acetic acid, $250 \mu \mathrm{l}$ of water) overnight at room temperature. Destaining solution $(500 \mathrm{ml}$ of water, $400 \mathrm{ml}$ of methanol, $100 \mathrm{ml}$ of acetic acid) was used for 2 h. Coommassie blue-stained gels were visualized using Gel Doc EZ Imager.

\section{ACKNOWLEDGMENTS}

We thank J.-F. Laliberte for providing the TuMV (6K2-GFP) construct; the Indiana University Light Microscopy Imaging Center for access to confocal microscopes; L. Joseph, Indiana University, for technical assistance; M. Peterson, R. Collier, M. Thompson, A. Miyamoto, and V. S. N. Lor at the Wisconsin Crop Innovation Center, Middleton, WI, U.S.A., for generating the transgenic soybean lines; S. Tolin for generously providing antibody for the SMV CP; and the United States Department of Agriculture Soybean Germplasm Collection for soybean seed.

\section{AUTHOR-RECOMMENDED INTERNET RESOURCE}

Wisconsin Crop Innovation Center soybean transformation homepage: https://cropinnovation.cals.wisc.edu/services/soybeantransformation-2

\section{LITERATURE CITED}

Adachi, H., Contreras, M. P., Harant, A., Wu, C. H., Derevnina, L., Sakai, T., Duggan, C., Moratto, E., Bozkurt, T. O., Maqbool, A., Win, J., and Kamoun, S. 2019. An N-terminal motif in NLR immune receptors is 
functionally conserved across distantly related plant species. eLife 8 : e49956.

Ade, J., DeYoung, B. J., Golstein, C., and Innes, R. W. 2007. Indirect activation of a plant nucleotide binding site-leucine-rich repeat protein by a bacterial protease. Proc. Natl. Acad. Sci. U.S.A. 104: 2531-2536.

Alfano, J. R., and Collmer, A. 2004. Type III secretion system effector proteins: Double agents in bacterial disease and plant defense. Annu. Rev. Phytopathol. 42:385-414.

Bonardi, V., Cherkis, K., Nishimura, M. T., and Dangl, J. L. 2012. A new eye on NLR proteins: Focused on clarity or diffused by complexity? Curr. Opin. Immunol. 24:41-50.

Bonardi, V., Tang, S., Stallmann, A., Roberts, M., Cherkis, K., and Dangl, J. L. 2011. Expanded functions for a family of plant intracellular immune receptors beyond specific recognition of pathogen effectors. Proc. Natl. Acad. Sci. U.S.A. 108:16463-16468

Bryksin, A. V., and Matsumura, I. 2010. Overlap extension PCR cloning: A simple and reliable way to create recombinant plasmids. Biotechniques 48:463-465.

Caldwell, K. S., and Michelmore, R. W. 2009. Arabidopsis thaliana genes encoding defense signaling and recognition proteins exhibit contrasting evolutionary dynamics. Genetics 181:671-684.

Carter, M. E., Helm, M., Chapman, A. V. E., Wan, E., Restrepo Sierra, A. M., Innes, R. W., Bogdanove, A. J., and Wise, R. P. 2019. Convergent evolution of effector protease recognition by Arabidopsis and barley. Mol. Plant-Microbe Interact. 32:550-565.

Chang, C., Yu, D., Jiao, J., Jing, S., Schulze-Lefert, P., and Shen, Q.-H 2013. Barley MLA immune receptors directly interfere with antagonistically acting transcription factors to initiate disease resistance signaling. Plant Cell 25:1158-1173.

Clough, S. J., and Bent, A. F. 1998. Floral dip: A simplified method for Agrobacterium-mediated transformation of Arabidopsis thaliana. Plant J. 16:735-743.

Cotton, S., Grangeon, R., Thivierge, K., Mathieu, I., Ide, C., Wei, T., Wang, A., and Laliberté, J. F. 2009. Turnip mosaic virus RNA replication complex vesicles are mobile, align with microfilaments, and are each derived from a single viral genome. J. Virol. 83: 10460-10471.

DeYoung, B. J., Qi, D., Kim, S.-H., Burke, T. P., and Innes, R. W. 2012. Activation of a plant nucleotide binding-leucine rich repeat disease resistance protein by a modified self protein. Cell. Microbiol. 14 1071-1084.

Dowen, R. H., Engel, J. L., Shao, F., Ecker, J. R., and Dixon, J. E. 2009. A family of bacterial cysteine protease type III effectors utilizes acylationdependent and -independent strategies to localize to plasma membranes. J. Biol. Chem. 284:15867-15879.

Earley, K. W., Haag, J. R., Pontes, O., Opper, K., Juehne, T., Song, K., and Pikaard, C. S. 2006. Gateway-compatible vectors for plant functional genomics and proteomics. Plant J. 45:616-629.

Gao, Z., Chung, E.-H., Eitas, T. K., and Dangl, J. L. 2011. Plant intracellular innate immune receptor Resistance to Pseudomonas syringae pv. maculicola 1 (RPM1) is activated at, and functions on, the plasma membrane. Proc. Natl. Acad. Sci. U.S.A. 108:7619-7624.

Gardner, M., Dhroso, A., Johnson, N., Davis, E. L., Baum, T. J., Korkin, D., and Mitchum, M. G. 2018. Novel global effector mining from the transcriptome of early life stages of the soybean cyst nematode Heterodera glycines. Sci. Rep. 8:2505.

Grant, M., Brown, I., Adams, S., Knight, M., Ainslie, A., and Mansfield, J. 2000. The RPM1 plant disease resistance gene facilitates a rapid and sustained increase in cytosolic calcium that is necessary for the oxidative burst and hypersensitive cell death. Plant J. 23:441-450.

$\mathrm{Gu}$, Y., and Innes, R. W. 2011. The KEEP ON GOING protein of Arabidopsis recruits the ENHANCED DISEASE RESISTANCE1 protein to trans-Golgi network/early endosome vesicles. Plant Physiol. 155: $1827-1838$

Hayashi, N., Inoue, H., Kato, T., Funao, T., Shirota, M., Shimizu, T., Kanamori, H., Yamane, H., Hayano-Saito, Y., Matsumoto, T., Yano, M., and Takatsuji, H. 2010. Durable panicle blast-resistance gene $\mathrm{Pbl}$ encodes an atypical CC-NBS-LRR protein and was generated by acquiring a promoter through local genome duplication. Plant J. 64: 498-510.

He, S. Y., Bauer, D. W., and Collmer, A. 1994. Hypersensitive response elicited by Erwinia amylovora harpin requires active plant metabolism. Mol. Plant-Microbe Interact. 7:289-292.

Helm, M., Qi, M., Sarkar, S., Yu, H., Whitham, S. A., and Innes, R. W. 2019. Engineering a decoy substrate in soybean to enable recognition of the soybean mosaic virus NIa protease. Mol. Plant-Microbe Interact. 32: 760-769.
Hu, Z., Zhou, Q., Zhang, C., Fan, S., Cheng, W., Zhao, Y., Shao, F., Wang, H. W., Sui, S. F., and Chai, J. 2015. Structural and biochemical basis for induced self-propagation of NLRC4. Science 350:399-404.

Jefferson, R. A., Kavanagh, T. A., and Bevan, M. W. 1987. GUS fusions: Beta-glucuronidase as a sensitive and versatile gene fusion marker in higher plants. EMBO J. 6:3901-3907.

Jia, Y., McAdams, S. A., Bryan, G. T., Hershey, H. P., and Valent, B. 2000. Direct interaction of resistance gene and avirulence gene products confers rice blast resistance. EMBO J. 19:4004-4014.

Keen, N. T., Ersek, T., Long, M., Bruegger, B., and Holliday, M. 1981. Inhibition of the hypersensitive reaction of soybean leaves to incompatible Pseudomonas spp. by blasticidin S, streptomycin or elevated temperature. Physiol. Plant Pathol. 18:325-337.

Kim, S. H., Qi, D., Ashfield, T., Helm, M., and Innes, R. W. 2016. Using decoys to expand the recognition specificity of a plant disease resistance protein. Science 351:684-687.

Lee, H.-Y., Mang, H., Choi, E.-H., Seo, Y.-E., and Kim, M.-S. 2020. Genomewide functional analysis of hot pepper immune receptors reveals an autonomous NLR cluster in seed plants. bioRxiv. Published online.

Lim, H. S., Jang, C.-Y., Bae, H.-H., Kim, J., Lee, C. H., Hong, J. S., Ju, H. J., Kim, H. G., and Domier, L. L. 2011. Soybean mosaic virus infection and helper component-protease enhance accumulation of bean pod mottle virus-specific siRNAs. Plant Pathol. J. 27:315-323.

Orbach, M. J., Farrall, L., Sweigard, J. A., Chumley, F. G., and Valent, B. 2000. A telomeric avirulence gene determines efficacy for the rice blast resistance gene Pi-ta. Plant Cell 12:2019-2032.

Peart, J. R., Mestre, P., Lu, R., Malcuit, I., and Baulcombe, D. C. 2005. NRG1, a CC-NB-LRR protein, together with N, a TIR-NB-LRR protein, mediates resistance against tobacco mosaic virus. Curr. Biol. 15:968-973.

Qi, D., DeYoung, B. J., and Innes, R. W. 2012. Structure-function analysis of the coiled-coil and leucine-rich repeat domains of the RPS5 disease resistance protein. Plant Physiol. 158:1819-1832.

Qi, D., Dubiella, U., Kim, S. H., Sloss, D. I., Dowen, R. H., Dixon, J. E., and Innes, R. W. 2014. Recognition of the protein kinase AVRPPHB SUSCEPTIBLE1 by the disease resistance protein RESISTANCE TO PSEUDOMONAS SYRINGAE5 is dependent on $S$-acylation and an exposed loop in AVRPPHB SUSCEPTIBLE1. Plant Physiol. 164: 340-351.

Raffaele, S., Win, J., Cano, L. M., and Kamoun, S. 2010. Analyses of genome architecture and gene expression reveal novel candidate virulence factors in the secretome of Phytophthora infestans. BMC Genomics 11:637.

Restrepo, M. A., Freed, D. D., and Carrington, J. C. 1990. Nuclear transport of plant potyviral proteins. Plant Cell 2:987-998.

Russell, A. R., Ashfield, T., and Innes, R. W. 2015. Pseudomonas syringae effector AvrPphB suppresses AvrB-induced activation of RPM1 but not AvrRpm1-induced activation. Mol. Plant-Microbe Interact. 28:727-735.

Shao, F., Golstein, C., Ade, J., Stoutemyer, M., Dixon, J. E., and Innes, R. W. 2003. Cleavage of Arabidopsis PBS1 by a bacterial type III effector. Science 301:1230-1233.

Shattuck, V. I. 2010. The biology, epidemiology, and control of turnip mosaic virus. Pages 199-238 in: Horticultural Reviews. John Wiley \& Sons, Inc., Oxford, U.K.

Shen, Q. H., Saijo, Y., Mauch, S., Biskup, C., Bieri, S., Keller, B., Seki, H., Ulker, B., Somssich, I. E., and Schulze-Lefert, P. 2007. Nuclear activity of MLA immune receptors links isolate-specific and basal diseaseresistance responses. Science 315:1098-1103.

Simonich, M. T., and Innes, R. W. 1995. A disease resistance gene in Arabidopsis with specificity for the avrPph3 gene of Pseudomonas syringae pv. phaseolicola. Mol. Plant-Microbe Interact. 8:637-640.

Slootweg, E., Roosien, J., Spiridon, L. N., Petrescu, A.-J., Tameling, W., Joosten, M., Pomp, R., van Schaik, C., Dees, R., Borst, J. W., Smant, G., Schots, A., Bakker, J., and Goverse, A. 2010. Nucleocytoplasmic distribution is required for activation of resistance by the potato NB-LRR receptor Rx1 and is balanced by its functional domains. Plant Cell 22: 4195-4215.

Swiderski, M. R., and Innes, R. W. 2001. The Arabidopsis PBS1 resistance gene encodes a member of a novel protein kinase subfamily. Plant J. 26 : 101-112.

Takemoto, D., Rafiqi, M., Hurley, U., Lawrence, G. J., Bernoux, M., Hardham, A. R., Ellis, J. G., Dodds, P. N., and Jones, D. A. 2012. Nterminal motifs in some plant disease resistance proteins function in membrane attachment and contribute to disease resistance. Mol. PlantMicrobe Interact. 25:379-392.

Tameling, W. I. L., Nooijen, C., Ludwig, N., Boter, M., Slootweg, E., Goverse, A., Shirasu, K., and Joosten, M. H. 2010. RanGAP2 mediates nucleocytoplasmic partitioning of the NB-LRR immune receptor Rx in the Solanaceae, thereby dictating Rx function. Plant Cell 22:4176-4194. 
Vinatzer, B. A., Teitzel, G. M., Lee, M. W., Jelenska, J., Hotton, S., Fairfax, K., Jenrette, J., and Greenberg, J. T. 2006. The type III effector repertoire of Pseudomonas syringae pv. syringae B728a and its role in survival and disease on host and non-host plants. Mol. Microbiol. 62:26-44.

Walsh, J. A., and Jenner, C. E. 2002. Turnip mosaic virus and the quest for durable resistance. Mol. Plant Pathol. 3:289-300.

Wan, J., Cabanillas, D. G., Zheng, H., and Laliberté, J.-F. 2015. Turnip mosaic virus moves systemically through both phloem and xylem as membrane-associated complexes. Plant Physiol. 167:1374-1388.

Wang, J., Hu, M., Wang, J., Qi, J., Han, Z., Wang, G., Qi, Y., Wang, H.-W., Zhou, J.-M., and Chai, J. 2019. Reconstitution and structure of a plant NLR resistosome conferring immunity. Science 364:eaav5870.
Wei, T., Huang, T.-S., McNeil, J., Laliberté, J.-F., Hong, J., Nelson, R. S., and Wang, A. 2010. Sequential recruitment of the endoplasmic reticulum and chloroplasts for plant potyvirus replication. J. Virol. 84:799-809.

Zhang, J., Li, W., Xiang, T., Liu, Z., Laluk, K., Ding, X., Zou, Y., Gao, M., Zhang, X., Chen, S., Mengiste, T., Zhang, Y., and Zhou, J. M. 2010. Receptor-like cytoplasmic kinases integrate signaling from multiple plant immune receptors and are targeted by a Pseudomonas syringae effector. Cell Host Microbe 7:290-301.

Zhang, Q., Li, W., Yang, J., Xu, J., Meng, Y., and Shan, W. 2020. Two Phytophthora parasitica cysteine protease genes, PpCys44 and PpCys45, trigger cell death in various Nicotiana spp. and act as virulence factors. Mol. Plant Pathol. 21:541-554. 